\title{
Constitutive activation and overexpression of NF-KB/C-Rel in conjunction with p50 contribute to aggressive tongue tumorigenesis
}

\author{
Shilpi Gupta ${ }^{1,2, *}$, Prabhat Kumar ${ }^{1,2, *}$, Harsimrut Kaur ${ }^{2}$, Nishi Sharma ${ }^{3}$, Sunita \\ Gupta $^{4}$, Daman Saluja ${ }^{2}$, Alok C. Bharti ${ }^{5}$ and Bhudev Das ${ }^{1,2}$ \\ ${ }^{1}$ Stem Cell and Cancer Research Lab, Amity Institute of Molecular Medicine and Stem Cell Research, Amity University Uttar \\ Pradesh, Sector-125, Noida-201313, India \\ ${ }^{2}$ Dr. B. R. Ambedkar Center for Biomedical Research, University of Delhi, Delhi-110007, India \\ ${ }^{3}$ Department of Otorhinolaryngology, Post Graduate Institute of Medical Education and Research, Dr. Ram Manohar Lohia \\ Hospital, Delhi-110010, India \\ ${ }^{4}$ Department of Oral Medicine and Radiology, Maulana Azad Institute of Dental Sciences, Delhi-110010, India \\ ${ }^{5}$ Molecular Oncology Laboratory, Department of Zoology, University of Delhi, Delhi-110007, India \\ *These authors contributed equally to this work
}

Correspondence to: Bhudev Das, email: bcdas48@hotmail.com, bcdas@amity.edu

Keywords: tongue squamous cell carcinoma; NF-KB/C-Rel; Fra-2; HPV; prognosis

Received: April 17, $2018 \quad$ Accepted: August 16, $2018 \quad$ Published: August 31, 2018

Copyright: Gupta et al. This is an open-access article distributed under the terms of the Creative Commons Attribution License 3.0 (CC BY 3.0), which permits unrestricted use, distribution, and reproduction in any medium, provided the original author and source are credited.

\section{ABSTRACT}

Tongue squamous cell carcinoma (TSCC) is a most aggressive head and neck cancer often associated with a poor survival rate. Yet, it always shows better prognosis in presence of HPV16 infection. NF-KB plays a pivotal role in carcinogenesis and chemo-radio resistance of cancer but its role in tongue cancer is not yet explored. In this study, a total of hundred tongue tissue biopsies comprising precancer, cancer and adjacent normal controls including two tongue cancer cell lines ( $\mathrm{HPV}^{+/-\mathrm{ve}}$ ) were employed to examine expression and transactivation of NF-kB proteins, their silencing by siRNA and invasion assays to understand their contributions in tongue carcinogenesis. An exclusive prevalence (28\%) of HR-HPV type 16 was observed mainly in well differentiated tumors (78.5\%). Increased DNA binding activity and differential expression of NF-KB proteins was observed with p50 and c-Rel being the two major DNA binding partners forming the functional NF-KB complex that increased as a function of severity of lesions in both $\mathrm{HPV}^{+/-v e}$ tumors but selective participation of p65 in HPV16 ${ }^{\text {tve }}$ TSCCs induced well differentiation of tumors resulting in better prognosis. siRNA treatment against c-Rel or Fra-2 led to upregulation of p27 but strong inhibition of c-Rel, c-Jun, c-myc, HPVE6/E7 and Fra-2 which is exclusively overexpressed in HPV-ve aggressive tumors. In conclusion, selective participation of c-Rel with p50 that in crosstalk with AP-1/Fra-2 induced poor differentiation and aggressive tumorigenesis mainly in HPV $^{\text {-ve }}$ smokers while HPV infection induced expression of p65 and p27 leading to well differentiation and better prognosis preferably in non-smoking TSCC patients.

\section{INTRODUCTION}

Tongue squamous cell carcinoma (TSCC) is one of the most common but a lethal head and neck malignancy [1]. It is a highly aggressive cancer with poor prognosis mostly prevalent in younger subjects [2-6]. Inspite of enormous advances in diagnosis and treatment, there is not much improvement in survival rate of TSCC patients. Therefore, understanding pathogenesis of tongue cancer is important to identify potential diagnostic and therapeutic target(s) for better management of the disease. Numerous clinicoepidemiological and molecular studies have established 
that the high incidence of TSCC is mainly associated with tobacco and alcohol consumption $[7,8]$ but infection with high-risk human papillomaviruses (HR-HPVs) is also recognized as an independent risk-factor [9]. Interestingly, head and neck squamous cell carcinomas (HNSCCs) including TSCCs always show a good prognosis and better survival in presence of HPV infection [3, 4, 6, 10-13]. However, it is not well understood how viral oncogenes regulate cellular and molecular pathogenic events that lead to better prognosis when treated.

The pro-inflammatory transcription factor $\mathrm{NF}-\kappa \mathrm{B}$ plays a pivotal role in regulating expression of genes and pathways that play a key role in initiation and progression of various cancers including tongue cancer. $\mathrm{NF}-\kappa \mathrm{B}$ has family of five major proteins (NF- $\kappa \mathrm{B} 1 / \mathrm{p} 50, \mathrm{NF}-\kappa \mathrm{B} 2 /$ $\mathrm{p} 52, \mathrm{RelA} / \mathrm{p} 65$, c-Rel and RelB) that form a functional homo/heterodimeric complex and the most abundant and active form is a heterodimer composed of p50 and p65 proteins [14]. The Rel family of proteins RelA, RelB and c-Rel possess a c-terminal domain responsible for transcriptional activation. Inflammatory response often activates $\mathrm{NF}-\kappa \mathrm{B}$ which gets translocated on to the nucleus and up or down several downstream gene expression. Numerous studies have reported differential expression and higher DNA binding activity of NF- $\kappa \mathrm{B}$ in different stages of various cancers [12, 15-19] including oral cancer [12] and it also leads to chemo-radiotherapy resistance, and poor prognosis [19]. An elevated level of c-Rel expression has also been shown to be associated with aggressive tumor phenotype [12, 20-22]. Either homo or hetero-dimerization of c-Rel with p50 has been reported to be associated with aggressive B- and T-cell lymphomas [23]. While it leads to the induction of apoptosis yet ectopic expression of c-Rel promoted therapy resistance [24]. In contrast, oral cancer often showed preferential p50/p50 homo-dimerization but HRHPV type 16 infection promoted selective participation of p65 leading to well differentiation and better prognosis of tumor [12]. These observations strongly suggest that $\mathrm{NF}-\kappa \mathrm{B}$ proteins represent a class of potential marker(s) for the progression and/or prognosis of oral tongue cancer. In this study, we report first time a differential functional regulatory role of $\mathrm{NF}-\kappa \mathrm{B} / \mathrm{c}-\mathrm{Rel} / \mathrm{p} 65$ and their target genes in presence or absence of HPV infection in a spectrum of tongue cancer tissues and cell lines and their role in tumor aggressiveness and drug resistance. We also show that c-Rel in crosstalk with AP-1/Fra-2, can induce aggressive tumor phenotype and poor prognosis in absence of HPV mostly in patients with tobacco habits while HPV16 infection induced well differentiation and better prognosis mostly in non-smoking TSCC patients.

\section{RESULTS}

To molecularly dissect the role of $\mathrm{NF}-\kappa \mathrm{B}$ in TSCC, prospectively collected one hundred fresh tongue tissue biopsies comprising precancer $(n=20)$, cancer $(n=50)$ and adjacent normal controls $(n=30)$ and a $\mathrm{HPV}^{+\mathrm{ve}}$ (UPCI:SCC090) and a HPV ${ }^{-\mathrm{ve}}$ (AW13516) tongue cancer cell lines were analyzed. Of twenty precancer cases, $11(55 \%)$ were either leukoplakia or erythroplakia and $9(45 \%)$ were dysplasia (Table 1A). DNA isolated from tissue specimens and cell lines were subjected to HPV detection and HPV genotyping while protein and RNA extracted were used for analysis of expression and DNA binding activity of NF- $\kappa \mathrm{B}$ family proteins. The clinico-epidemiological and demographic details along with HPV status of all patients are presented in Table 1A. The results demonstrate that the majority of cancer patients were smokers $(84 \% ; 42 / 50)$ and males $(40 / 50 ; 80 \%)$ with a mean age of $40.48 \pm 12.46$ years but $60 \%$ patients were below 35 years of age with advanced tumor grades (T3/T4; $60 \%$ ) and stages (III/IV; 72\%), and node negative. Out of 50 tongue cancer cases, $15(30 \%)$ were well differentiated squamous cell carcinomas (WDSCCs), 8 (16\%) were moderately differentiated (MDSCCs) while 27 (54\%) were poorly differentiated squamous cell carcinomas (PDSCCs).

\section{Exclusive prevalence of HPV 16 infection mainly in non-smoking patients}

DNA extracted from tissue biopsy specimens comprising precancer, cancer and adjacent normal controls including two cell lines were tested for the presence of HPV infection, first by consensus primers, then by HPV type-specific PCR followed by reverse line blot assay (RLB) which revealed 14 TSCCs (28\%) exclusively positive for HR-HPV type 16 and rest all cases were found to be negative for HPV (Table 1A and Supplementary Figure 1A-1C). The majority of $\mathrm{HPV}^{+\mathrm{ve}}$ TSCCs $(57.2 \% ; 8 / 14, p=0.0002)$ were females who showed well differentiated tumors (see Table 1A) of early grades (stage I-II). Interestingly, a significantly higher prevalence of HPV infection was observed in non-tobacco smoking $(75 \%, 6 / 8 ; p \leq 0.01)$ TSCC patients who were mainly $(75 \% ; 6 / 8)$ women while majority were smokers and negative for HPV infection $(94.4 \% ; p=0.003)$. In contrast, majority of TSCC patients were males $(80 \%)$ and all were smokers but only $15 \%(6 / 40)$ of them were positive for HPV infection (Supplementary Figure 1D).

\section{Higher DNA binding activity and transactivation of $N F-\kappa B$ contributed by preferential heterodimerization of p50/c-Rel during tongue carcinogenesis}

To investigate the structural and functional role of NF- $\mathrm{KB}$ during tongue carcinogenesis, we have analyzed the DNA binding activity of NF- $\mathrm{KB}$ and its family proteins in TSCC tissues and cell lines by gel shift assay. The constitutive activation of NF- $\mathrm{BB}$ as revealed by gradual increase in DNA binding activity of 
Table 1A: Clinico-pathological and demographic characteristics and their correlation with HPV16 infection in tongue cancer patients

\begin{tabular}{|c|c|c|c|c|c|}
\hline \multicolumn{2}{|c|}{ Characteristics } & \multirow{2}{*}{$\begin{array}{c}\text { No. of cases (\%) } \\
30\end{array}$} & \multirow{2}{*}{$\begin{array}{c}\begin{array}{c}\text { Total HPV } \\
\text { positive }\end{array} \\
\text { nil }\end{array}$} & \multirow{2}{*}{$\begin{array}{c}\text { HPV negative } \\
-\end{array}$} & \multirow{2}{*}{$\begin{array}{c}p \text {-values } \\
-\end{array}$} \\
\hline $\begin{array}{l}\text { Adjacent normal } \\
\text { controls }\end{array}$ & & & & & \\
\hline Precancer $(n=20)$ & $36.7 \pm 5.99$ & Mean age \pm SD & nil & - & \multirow{3}{*}{-} \\
\hline \multirow{2}{*}{ Precancer $(n=20)$} & Leukoplakia/Erthroplakia & $11(55 \%)$ & nil & - & \\
\hline & Dysplasia & $9(45 \%)$ & nil & - & \\
\hline Cancer $(n=50)$ & $40.48 \pm 12.46$ & Mean age \pm SD & $14(28 \%)$ & $36(72 \%)$ & \\
\hline \multirow{2}{*}{ Age ranges } & $<35$ & $30(60 \%)$ & $10(71.4 \%)$ & $20(55.6 \%)$ & \multirow{2}{*}{$0.3(\mathrm{~ns})$} \\
\hline & $>35$ & $20(40 \%)$ & $4(28.6 \%)$ & $16(44.4 \%)$ & \\
\hline \multirow{2}{*}{ Gender } & Male & $40(80 \%)$ & $6(42.9 \%)$ & $34(94.4 \%)$ & \multirow{2}{*}{0.0002} \\
\hline & Female & $10(20 \%)$ & $8(57.2 \%)$ & $2(5.6 \%)$ & \\
\hline \multirow{2}{*}{ Religion } & Hindu & $40(80 \%)$ & $13(92.9 \%)$ & $27(75 \%)$ & \multirow{2}{*}{$0.2(\mathrm{~ns})$} \\
\hline & Muslim & $10(20 \%)$ & $1(7.1 \%)$ & $9(25 \%)$ & \\
\hline \multirow[t]{2}{*}{ Addiction habits } & Tobacco smokers & $42(84 \%)$ & $8(57.1 \%)$ & $34(94.4 \%)$ & \multirow{2}{*}{0.003} \\
\hline & Non-smokers & $8(16 \%)$ & $6(42.9 \%)$ & $2(5.6 \%)$ & \\
\hline \multirow[b]{2}{*}{ Tumor site } & Base of tongue & $22(44 \%)$ & $12(85.7 \%)$ & $10(27.8 \%)$ & \multirow[b]{2}{*}{0.0003} \\
\hline & $\begin{array}{l}\text { Mobile tongue \& other } \\
\text { sites of tongue }\end{array}$ & $28(56 \%)$ & $2(14.3 \%)$ & $26(72.2 \%)$ & \\
\hline \multirow{3}{*}{ Differentiation status } & WDSCC & $15(30 \%)$ & $11(78.6 \%)$ & $4(11.2 \%)$ & \multirow{3}{*}{0.0001} \\
\hline & MDSCC & $8(16 \%)$ & $2(14.3 \%)$ & $6(16.7 \%)$ & \\
\hline & PDSCC & $27(54 \%)$ & $1(7.1 \%)$ & $26(72.2 \%)$ & \\
\hline \multirow{2}{*}{ Tumor status } & T1-T2 & $20(40 \%)$ & $11(78.6 \%)$ & $9(25 \%)$ & \multirow{2}{*}{0.0009} \\
\hline & $\mathrm{T} 3-\mathrm{T} 4$ & $30(60 \%)$ & $3(21.4 \%)$ & $27(75 \%)$ & \\
\hline \multirow{2}{*}{ Node status } & No-N1 & $39(78 \%)$ & $13(92.9 \%)$ & $26(72.2 \%)$ & \multirow{2}{*}{$0.2(\mathrm{~ns})$} \\
\hline & $\mathrm{N} 2-\mathrm{N} 3$ & $11(22 \%)$ & $1(7.1 \%)$ & $10(27.8 \%)$ & \\
\hline \multirow{2}{*}{ Clinical staging } & Stage I-II & $14(28 \%)$ & $10(71.4 \%)$ & $4(11.1 \%)$ & \multirow{2}{*}{0.0001} \\
\hline & Stage III-IV & $36(72 \%)$ & $4(28.6 \%)$ & $32(88.9 \%)$ & \\
\hline
\end{tabular}

$\mathrm{n}$ : number of patients. T: primary tumor. N: regional lymph node. All cases comprised adjacent normal controls, precancer, $\mathrm{HPV}^{-v e}$ and HPV16 ${ }^{+v e}$ cancer patients. p-values obtained by probability Fisher's (exact) test using Graph Pad Prism 6.0. $p$-values $\leq 0.05$ are considered as statistically significant. $\mathrm{ns}=$ not significant.

$\mathrm{NF}-\kappa \mathrm{B}$ with increasing severity of the tongue lesions was observed (see Figure 1A-1C). Interestingly, there was a clear difference in binding activity of NF- $\kappa \mathrm{B}$ between $\mathrm{HPV}^{+\mathrm{ve}}$ and $\mathrm{HPV}^{-\mathrm{ve}}$ tumors; a little higher DNA binding was observed in $\mathrm{HPV}^{-\mathrm{ve}} \mathrm{TSCC}$ cases (Figure 1B). The specificity of NF- $\kappa \mathrm{B}$ binding activity was confirmed by performing cold competition assays with $100 \times$ molar excess of homologous NF- $\kappa \mathrm{B}$ and a heterologous Oct-1 as an internal control (Figure 1D, 1E).
To analyze the composition of functional NF- $\kappa \mathrm{B}$ complex in presence and absence of HPV infection, gel supershift assays were performed using specific antibodies (Santacruz, USA) raised against all five NF- $\kappa$ B family proteins; p50, p52, p65, c-Rel and RelB. The gel supershift assay revealed a differential DNA binding pattern and difference in composition of NF- $\kappa \mathrm{B}$ complex. p50 was the major DNA binding partner involved in the formation of functional NF- $\kappa \mathrm{B}$ complex in both $\mathrm{HPV}^{+/-\mathrm{ve}}$ tumors 
(Figure 2A, 2B) but majority of the $\mathrm{HPV}^{-\mathrm{ve}}(27 / 36$; $75 \%$ ) and poorly differentiated tumors showed minor but consistent involvement of c-Rel $(\sim 15-25 \%)$ with p50 $(\sim 80-90 \%)$ in the functional NF-kB complex (Figure 2B and Table 1B). In contrast, the majority $(11 / 14 ; 78.6 \%)$ of $\mathrm{HPV}^{+v e}$ and well differentiated tumors showed selective participation of p65 $(\sim 10-50 \%)$ in addition to p50-c-Rel (Figure 2A and Table 1B). No shift was observed for other NF- $\mathrm{KB}$ family proteins in both $\mathrm{HPV}^{+/-v e}$ tumors. In almost all tumors, more than $90 \%$ of supershifted bands were formed by p50/p50 homodimers with minor but consistent involvement of c-Rel in most of the higher grade tumors indicating a critical role of $\mathrm{p} 50 / \mathrm{c}-\mathrm{Rel}$ proteins in generation of functional NF- $\mathrm{KB}$ complex and transactivation during development of TSCC (Figure 2A, 2B, Table 1B). When we compared these findings with that of TSCC cell lines, p50 and c-Rel also form the functional NF-KB in $\mathrm{HPV}^{-v \mathrm{ve}}$ cells (AW13516) (Figure 2C) whereas $\mathrm{HPV}^{+v e}$ cells (UPCI: SCC090) showed regular participation of p65 along with p50 (Figure 2D); however, no involvement of c-Rel was found in the functional NF- $\mathrm{BB}$ complex formation.

\section{Expression of NF- $\kappa \mathrm{B}$ family proteins increased as a function of severity of tongue lesions}

To determine the pattern and level of expression of NF- $\mathrm{\kappa B}$ family proteins during TSCC, immunoblotting experiments were performed with cellular proteins extracted from tongue tumors and adjacent controls and cell lines. As illustrated in the Figure 3A, significantly a higher expression of NF- $\mathrm{\kappa B}$ family proteins; $\mathrm{p} 50$ (34/50, $68 \% ; p=0.0002), \mathrm{p} 52(29 / 50,58 \% ; p=0.0001), \mathrm{p} 65$ $(30 / 50,60 \% ; p=0.0001)$ and c-Rel $(37 / 50,74 \%$; $p=0.0001)$ was observed in majority of tongue cancer cases as compared to adjacent normal controls (Figure 3A and Table 1C). On the other hand, precancer cases showed moderate expression of p50 (10/20, 50\%), p52 (11/20, $55 \%)$ and $\mathrm{c}-\operatorname{Rel}(11 / 20,55 \% ; p=0.008)$ proteins (Figure $3 \mathrm{~A}$ and Table 1C). Immunoblotting data well corroborated with the results obtained from band supershift assays
A

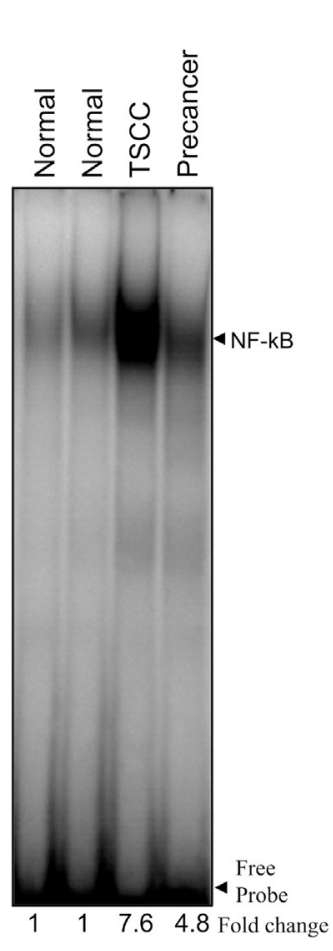

B

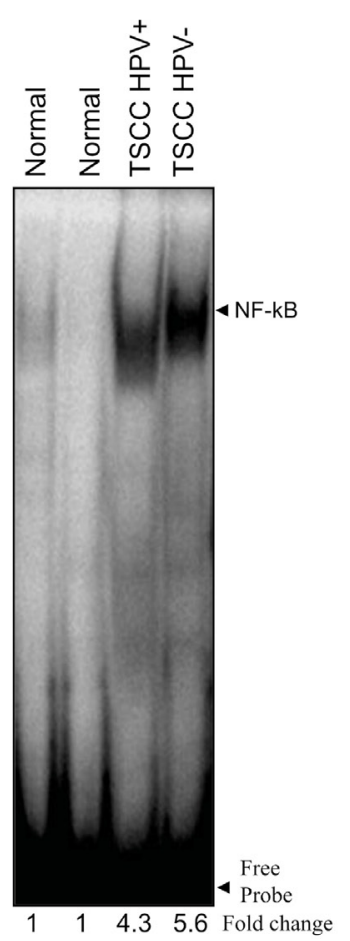

C

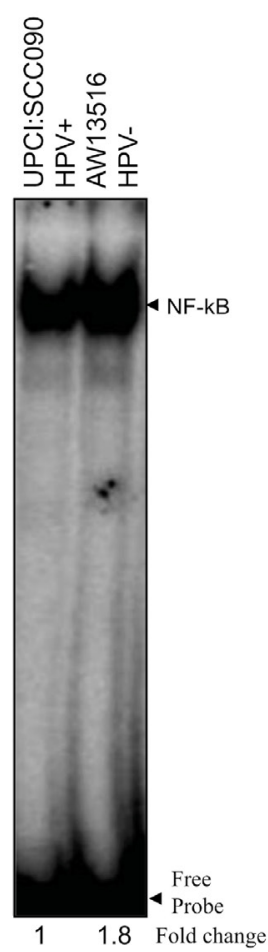

D

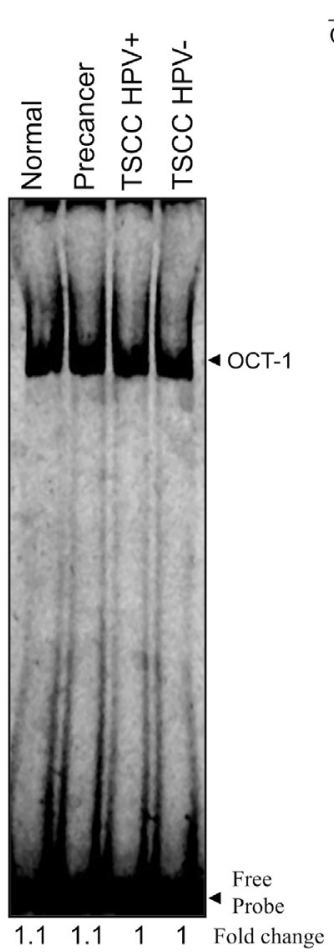

E

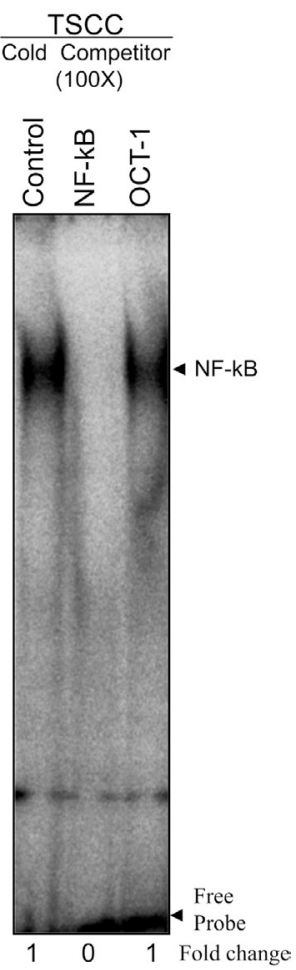

Figure 1: (A-E) Higher NF-кB DNA binding activity in $\mathrm{HPV}^{+\mathrm{ve}}$ and $\mathrm{HPV}^{-\mathrm{ve}}$ tongue tumor tissues and cell lines. Gel-shift assays showing NF- $\kappa B$ DNA binding activity in nuclear extracts $(10 \mu \mathrm{g})$ from different grades of tongue tumor tissues including normal controls (A, B) and cell lines (C) using $\gamma^{32} \mathrm{P}$ - ATP-radiolabeled oligonucleotide harbouring an NF- $\kappa \mathrm{B}$ consensus sequence. Increasing NF- $\kappa \mathrm{B}$ DNA binding activity was observed as the severity of tongue lesions progressed from normal to precancer to invasive cancer in

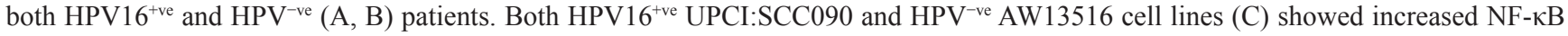
DNA binding activity but relatively higher in $\mathrm{HPV}^{-\mathrm{ve}}$ cells. (D) EMSA with labeled Oct-1 probe showed similar DNA binding activity in all grades of tongue tissues. Binding specificity was confirmed in a competition assay with a $100 \times$ molar exess addition of the specific cold competitor (NF- $\mathrm{KB}$ ) probe and nonspecific competitor Oct-1 probe and checked by EMSA (E). Densitometric analysis of band intensities of NF- $\kappa \mathrm{B}$ are indicated below each lane. 
(Figure 2A, 2B, Table 1B). RelB (25/50, 50\%; $p=0.03)$ showed an inconsistent pattern of expression.

When, we correlated expression pattern of NF$\kappa \mathrm{B}$ family proteins between $\mathrm{HPV}^{+v e}$ and $\mathrm{HPV}^{-\mathrm{ve}}$ tongue cancer cases, a slightly higher expression of p50, p52 and c-Rel proteins was observed mainly in $\mathrm{HPV}^{-\mathrm{ve}}$ cases as compared to HPV16 ${ }^{+v e}$ TSCCs that selectively overexpressed p65 protein (Figure 3A and Table 1C). A good correlation has been observed between the increasing expression pattern of p50, p52, p65 and c-Rel and the severity of tongue cancer lesions as they progressed from normal to precancer to malignant phenotype. TSCC cell lines also showed similar strong expression of $\mathrm{p} 50$, p52, p65, c-Rel including RelB in both $\mathrm{HPV}^{+/ \text {ve }}$ tongue cancer cells, however, the extent of c-Rel expression was distinctly higher in $\mathrm{HPV}^{-\mathrm{ve}}$ cells (Figure 3B).

\section{Overexpression of NF-кB family gene transcripts during TSCC}

Since most of the TSCCs displayed generalized increase in the expression of NF-KB proteins, we next examined their gene transcripts in total RNA isolated from tongue tissue biopsies of cancer, precancer and normal controls including tongue cancer cell lines by NF- $\mathrm{KB}$ family gene-specific qRT-PCR. The majority of tongue cancer cases showed higher level of expression of p50, p65 and c-Rel transcripts as compared to precancer and normal controls and the level of transcripts increased gradually as the lesions progressed to malignant phenotype (Figure 3C). These results well corroborated with the results of immunoblotting (Figure 3A, 3B) and gel supershift assays (Figure 2A, 2B). Similar results were recorded in tongue cancer cell lines where the level of p65 transcript was specifically higher in $\mathrm{HPV}^{+v e}$ cells (Figure 3D).

\section{c-Rel activates c-myc and c-Jun but downregulates p27 expression}

Since c-Rel, is often found activated and overexpressed in TSCCs, we examined the expression of its target genes; c-myc, c-Jun and p27 by immunoblotting. Enhanced expression of c-Rel led to activation of its downstream target genes such as c-myc, c-Jun and CDK but down-regulation of p27 leading to enhanced cell proliferation and aggressive tumor progression. The results
A

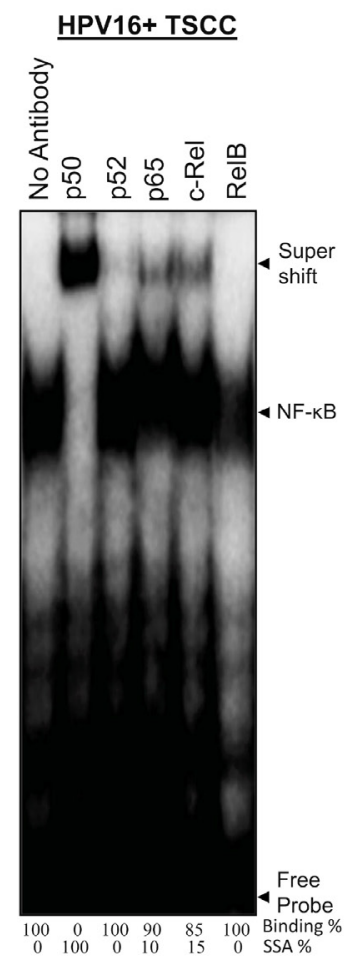

B

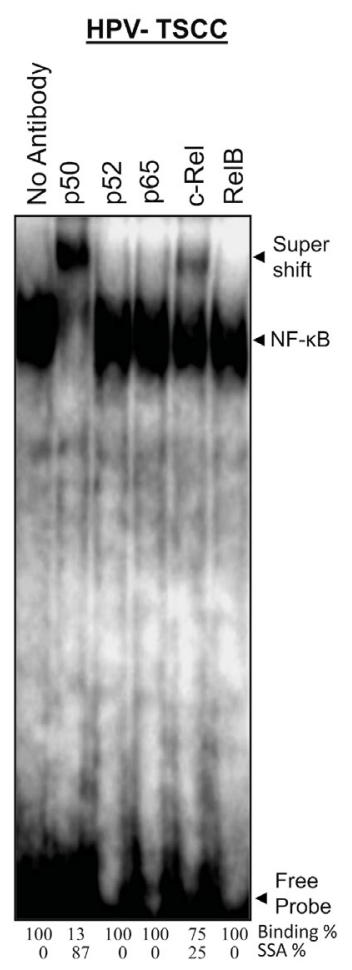

C

AW13516: HPV-

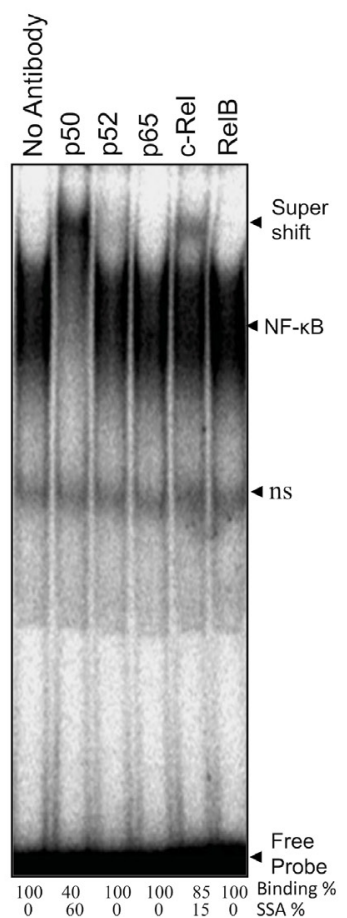

D

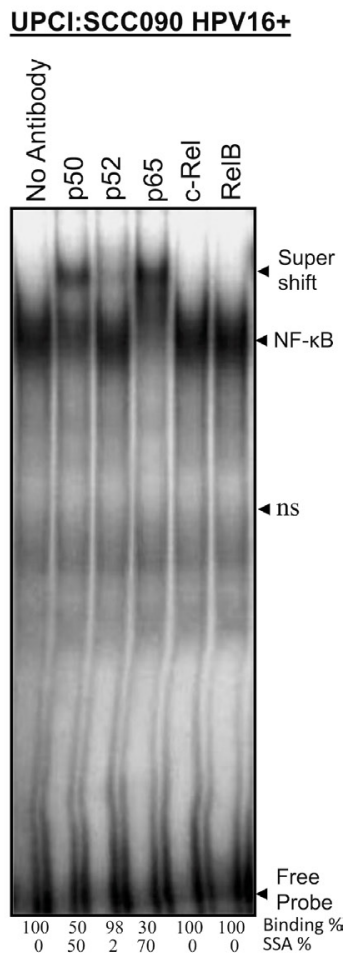

Figure 2: (A-D) Differential composition of NF- $\kappa B$ complex formation in $\mathrm{HPV}^{+\mathrm{ve}}$ and $\mathrm{HPV}^{-\mathrm{ve}}$ tongue tumor tissues and cell lines. Gelsupershift assays using specific antibodies against NF-кB proteins; p50, p52, p65, c-Rel \& RelB. Panel A, B, C and D showing differential

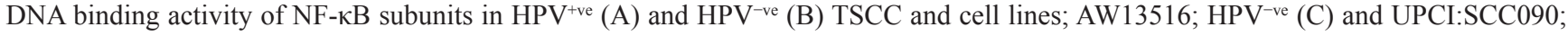
$\mathrm{HPV}_{16}{ }^{+\mathrm{ve}}(\mathrm{D})$. In all panels (A-D) significantly a higher binding activity of p50 which forms the major part $(\sim 90 \%)$ of functional NF- $\mathrm{kB}$ complex. HPV ${ }^{-v e}$ TSCC (panel B) consistently shows a minor participation of c-Rel with p50 and while p65 selectively participates in $\mathrm{HPV}^{+\mathrm{ve}}$ tumors (panel A). Lane No antibody for panel A-D, used as negative control. The intensities of super-shifted bands indicated and quantified in densitometric analysis. NS; non-specific binding. 
Table 1B: Analysis of binding patterns of NF-KB family proteins in $\mathrm{HPV}^{+{ }^{+v e}} \& \mathrm{HPV}^{-\mathrm{ve}}$ tongue cancer cases by band super shift assay

\begin{tabular}{|c|c|c|c|c|c|c|c|c|c|}
\hline \multirow{3}{*}{$\begin{array}{l}\text { NF-кB family } \\
\text { proteins }\end{array}$} & \multicolumn{8}{|c|}{$\operatorname{TSCC}(n=50)$} & \multirow{3}{*}{$p$-values } \\
\hline & \multicolumn{4}{|c|}{ HPV16 positive TSCC $(n=14)$} & \multicolumn{4}{|c|}{ HPV negative TSCC $(n=36)$} & \\
\hline & $\begin{array}{c}\text { Nil } \\
-\end{array}$ & $\begin{array}{c}\text { Weak } \\
\quad+\end{array}$ & $\begin{array}{c}\text { Moderate } \\
++\end{array}$ & $\begin{array}{c}\text { Strong } \\
++++\end{array}$ & $\begin{array}{c}\text { Nil } \\
-\end{array}$ & $\begin{array}{c}\text { Weak } \\
+\end{array}$ & $\begin{array}{c}\text { Moderate } \\
++\end{array}$ & $\begin{array}{c}\text { Strong } \\
++++\end{array}$ & \\
\hline P50 & - & 1 & 4 & 9 & 3 & 4 & 5 & 24 & $0.41(\mathrm{~ns})$ \\
\hline P52 & 14 & - & - & - & 36 & - & - & - & $1.0(\mathrm{~ns})$ \\
\hline P65 & 3 & 2 & 9 & - & 36 & - & - & - & 0.0001 \\
\hline c-Rel & - & 4 & 10 & - & 9 & 7 & 19 & 1 & $0.35(\mathrm{~ns})$ \\
\hline RelB & 14 & - & - & - & 36 & - & - & - & $1.0(\mathrm{~ns})$ \\
\hline
\end{tabular}

*Data represent DNA binding activity of NF- $\mathrm{kB}$ family proteins in $>90 \%$ of cases with minor changes in few cases.

Arbitrary level of DNA binding in band supershift assay: nil/not detectable (-); Weak (+); Moderate (++); Strong (+++).

$p$-value obtained by probability Fisher's (exact) test using Graph Pad Instat (6.0) comparing the DNA binding of NF$\kappa \mathrm{B}$ family members (nil + weak Vs moderate + strong) among $\mathrm{HPV}^{\text {tve }}$ cancer Vs $\mathrm{HPV}^{-\mathrm{ve}}$ cancer. $p$-values $\leq 0.05$ are considered as statistically significant. ns $=$ not significant.

revealed significantly a higher expression of c-myc $(38 / 50$, $76 \% ; p=0.0001)$ and $\mathrm{c}-\mathrm{Jun}(30 / 50,60 \% ; p=0.0001)$ in majority of tumors as compared to precancer and controls (Figure 3E, Table 1C). Interestingly, the magnitude of overexpression of these proteins was relatively higher in HPV $^{-v e}$ tumors (Figure 3E, Table 1D) though; not statistically significant. In contrast, majority (29/50, $58 \% ; p=0.002$ ) of tumors showed significantly a low or undetectable expression of p27 which was relatively higher in normal controls (Figure 3E). It is interesting to note here that along with c-myc and AP-1/c-Jun, Fra-2 was also highly upregulated in both TSCC tissues and cell lines and their levels were highly pronounced in $\mathrm{HPV}^{-v e}$ cells, whereas, p27 obviously showed low level of expression in both $\mathrm{HPV}^{+/-v e}$ cells (Figure 3F).

\section{c-Rel siRNA selectively downregulates $\mathrm{NF}-\kappa \mathrm{B} / \mathrm{c}-$ Rel expression in TSCC cells}

Our results demonstrate consistent involvement of c-Rel in the formation of functional NF- $\mathrm{kB}$ complex, DNA binding activity and transactivation. To explore it further, in the next part of our investigation, we examined the effect of in-vitro silencing of c-Rel in both the $\mathrm{HPV}^{+v e}$ and $\mathrm{HPV}^{-v e}$ tongue cancer cells using specific commercially synthesized small interfering RNA (siRNA) raised against c-Rel. The cells were transiently transfected with a pool of c-Rel-specific siRNA at a concentration of $40 \mathrm{nM}, 80 \mathrm{nM}$ and $120 \mathrm{nM}$ for 48 hours. Western blot analysis was performed to check efficiency of c-Rel knockdown and its effect on the expression of NF- $\mathrm{KB}$ family proteins. Cells transfected with scrambled siRNA $(120 \mathrm{nM})$ served as control. Transfection of TSCC cells by increasing concentration ( $40 \mathrm{nM}-120 \mathrm{nM}$ ) of c-Rel siRNA demonstrated a dose-dependent decline in the expression of c-Rel protein while its expression remained unaltered in scrambled siRNA treated cells (Figure 4A, 4B). The c-Rel suppression was observed even at concentration as low as $40 \mathrm{nM}$ and it was completely inhibited at $120 \mathrm{nM}$ in both $\mathrm{HPV}^{+- \text {ve }}$ cells (Figure 4A, 4B). This was accompanied by reduction in RelB expression however, p50, p52 and p65 expression remained unaffected (Figure 4A, 4B). The effect of c-Rel siRNA on cell proliferation was examined microscopically using trypan blue dye exclusion assay. As depicted (Supplementary Figure 2A, 2B), the cultures showed about $30-40 \%$ reduction in cell proliferation after c-Rel-siRNA treatment as compared to untreated or scrambled-siRNA treated controls (Supplementary Figure 2A, 2B).

\section{Inhibition of c-Rel down-regulates c-myc, c-Jun, Fra-2 and HPV16 E6/E7 but induces p27Kip1 expression in TSCC cells}

To investigate whether silencing of c-Rel affects the expression of downstream genes c-myc, c-Jun, p27 and HPV16 E6/E7 involved in TSCC carcinogenesis, we transfected TSCC cells (UPCI:SCC090 and AW13516) with different concentration of c-Rel siRNA for 48 hours. The transfection efficiency of c-Rel was analysed by western blotting. The maximum ( $95 \%)$ transfection efficiency of c-Rel was achievable at $120 \mathrm{nM}$ in both $\mathrm{HPV}^{+\mathrm{ve} / \text {-ve }}$ cell lines (Figure 4C-4E, upper panel). The results of c-Rel knockdown showed inhibition of c-Rel was accompanied by reduced expression of c-myc and c-Jun (Figure 4C, 4D) which were more prominent in 
$\mathrm{HPV}^{+\mathrm{ve}}$ UPCI:SCC090 cells (Figure 4D). An inverse effect was observed in the expression of p27 protein that was markedly increased with increasing concentrations of c-Rel siRNA irrespective of the HPV status (Figure 4C, 4D). Following c-Rel siRNA treatment, the expression of HPV16 E6/E7 was also reduced but only at the highest concentration (Figure 4E). Interestingly enough, when we checked the effect of c-Rel siRNA on AP-1/Fra-2 which was shown to be highly overexpressed in TSCCs [6], a significant reduction in Fra-2 expression was observed in both $\mathrm{HPV}^{+/-v e}$ cells (Figure 5A, 5B). It indicates that there exists a cross-talk between Fra-2 and c-Rel during tongue tumorigenesis.

\section{Fra-2 siRNA downregulates c-Rel indicating a possible cross-talk between the two genes contributing to aggressive TSCC}

We have recently demonstrated that selective participation and overexpression of Fra-2 in presence of c-Jun is associated with aggressive tumor phenotype of $\mathrm{HPV}^{-\mathrm{ve}}$ TSCCs and its selective silencing by Fra-2-siRNA suppressed tumor metastasis [6]. This finding prompted us to re-examine the extent of contribution of Fra- 2 in the functional activity of c-Rel in inducing aggressive tongue tumorigenesis. Interestingly, we found a remarkable
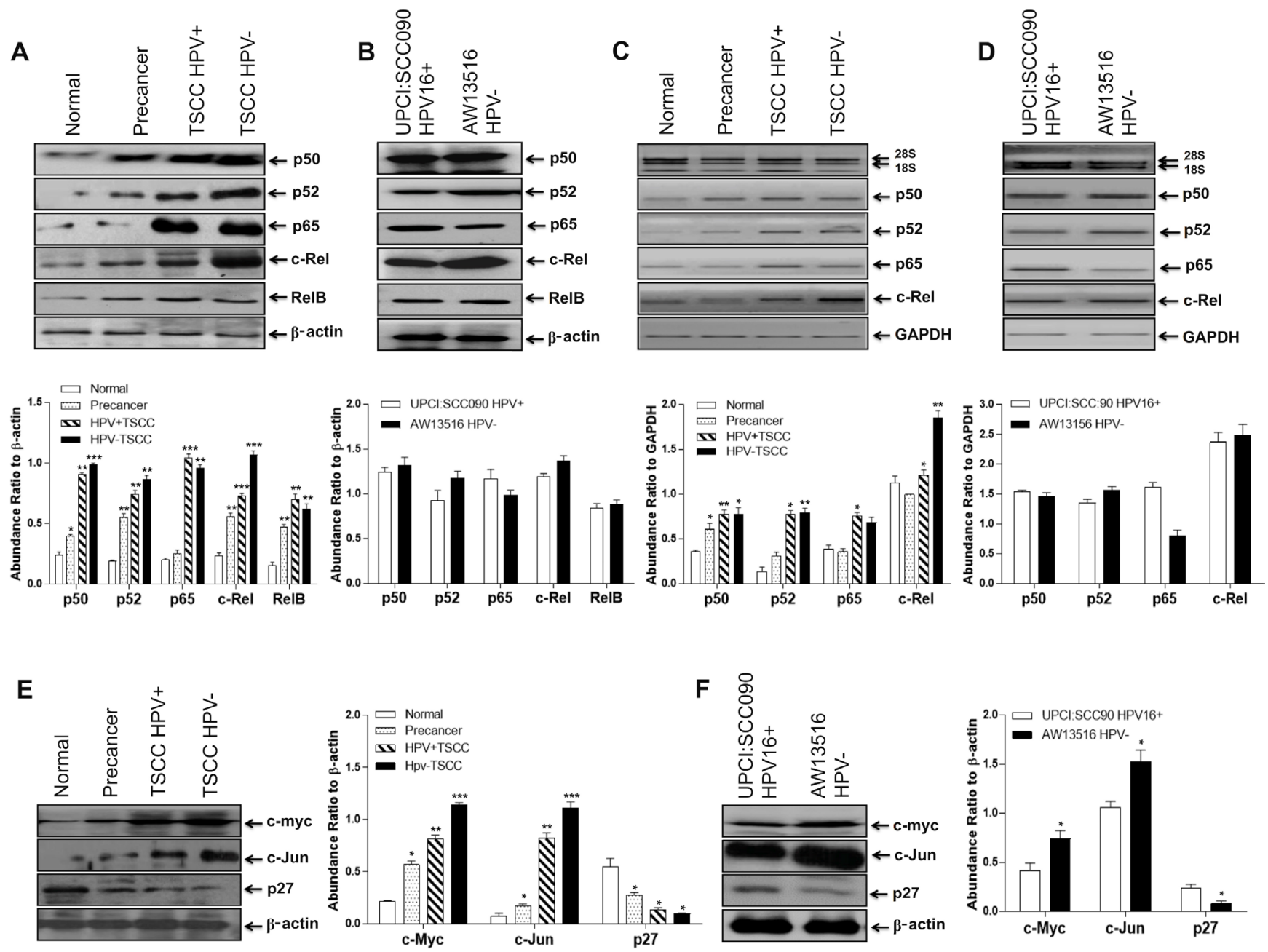

Figure 3: (A-F) Differential expression pattern of NF- $\mathrm{kB}$ proteins and their target genes in different grades of tongue tissues and cell lines. Representative immunoblots showing differentially overexpressed NF- $\mathrm{KB}$ proteins and their target genes (c-myc and c-Jun) in tongue tumor biopsies (A) and cell lines (B). $40 \mu \mathrm{g}$ cellular protein from tongue tissues or cell lines were resolved on 10\% SDS-PAGE, electrotransferred and probed with specific antibodies against all NF- $\mathrm{B}$ family proteins (p50, p52, p65, c-Rel \& RelB) and their target genes (c-myc, c-Jun and p27). To confirm equal protein loading, the membranes were stripped and re-probed for $\beta$-actin expression and quantitation of bands was performed by densitometric analysis showing in graphical panel of A, B. RT-PCR showing elevated mRNA expression profile of p50, p52, p65 \& c-Rel transcripts in tongue tumor tissues (C) and tumor cell lines (D). GAPDH gene was used as internal loading control (lower panel of C \& D). Panel E, F; show differential expression of c-myc, c-Jun and p27 genes in $\mathrm{HPV}^{+\mathrm{ve}}$ and HPV $\mathrm{H}^{-\mathrm{ve}}$ tongue tumor tissues (E) and cell lines (F). $\beta$-actin gene was used as an internal control (lower panels of E, F). Significant $(p<0.05)$ when compared with control vs. cases and $\mathrm{HPV}^{+v e}$ vs. HPV ${ }^{-v e}$ cell lines. The data in bar diagram are expressed as the mean $( \pm \mathrm{SEM}$ or $\pm \mathrm{SD})$ of three independent experiments. ${ }^{*} p<0.05 \&{ }^{* *} p<0.01,{ }^{* * *} p<0.001 \&{ }^{* * *} p<0.0001$. 
Table 1C: Expression of NF-אB family members \& their target genes products in tongue precancer, cancer and normal control cases

\begin{tabular}{|c|c|c|c|c|c|c|c|c|c|c|c|c|c|}
\hline \multirow{2}{*}{$\begin{array}{l}\text { Target } \\
\text { proteins }(\downarrow)\end{array}$} & \multicolumn{4}{|c|}{ Adjacent normal controls $(n=30)$} & \multicolumn{4}{|c|}{$\begin{array}{l}\text { Precancer } \\
(n=20)\end{array}$} & \multicolumn{4}{|c|}{$\begin{array}{c}\text { TSCC } \\
(n=\mathbf{5 0})\end{array}$} & \multirow{2}{*}{ p-value } \\
\hline & Nil (-) & $\begin{array}{c}\text { Weak } \\
(+)\end{array}$ & $\begin{array}{c}\text { Moderate } \\
(++)\end{array}$ & $\begin{array}{l}\text { Strong } \\
(++++)\end{array}$ & $\begin{array}{l}\text { Nil } \\
(-)\end{array}$ & $\begin{array}{c}\text { Weak } \\
(+)\end{array}$ & $\begin{array}{l}\text { Moderate } \\
\qquad(++)\end{array}$ & $\begin{array}{l}\text { Strong } \\
(++++)\end{array}$ & $\begin{array}{r}\text { Nil } \\
(-)\end{array}$ & $\begin{array}{c}\text { Weak } \\
(+)\end{array}$ & $\begin{array}{c}\text { Moderate } \\
\qquad(++)\end{array}$ & $\begin{array}{l}\text { Strong } \\
(++++)\end{array}$ & \\
\hline P50 & 2 & 9 & 14 & 5 & 2 & 4 & 10 & 4 & - & 2 & 14 & 34 & \\
\hline $\begin{array}{l}\text { Cases in } \\
\text { statistical } \\
\text { group (\%) }\end{array}$ & \multicolumn{2}{|c|}{$11(36.6 \%)$} & \multicolumn{2}{|c|}{$19(63.4 \%)$} & \multicolumn{2}{|c|}{$6(30 \%)$} & \multicolumn{2}{|c|}{$14(70 \%)$} & \multicolumn{2}{|c|}{$2(4 \%)$} & \multicolumn{2}{|c|}{$48(96 \%)$} & $\begin{array}{c}0.7^{1}, \mathbf{0 . 0 0 0 2}^{2}, \\
\mathbf{0 . 0 0 5}^{3}\end{array}$ \\
\hline P52 & 5 & 10 & 12 & 3 & 1 & 5 & 11 & 3 & - & 1 & 20 & 29 & \\
\hline $\begin{array}{l}\text { Cases in } \\
\text { statistical } \\
\text { group (\%) }\end{array}$ & \multicolumn{2}{|c|}{$15(50 \%)$} & \multicolumn{2}{|c|}{$15(50 \%)$} & \multicolumn{2}{|c|}{$6(30 \%)$} & \multicolumn{2}{|c|}{$14(70 \%)$} & \multicolumn{2}{|c|}{$1(2 \%)$} & \multicolumn{2}{|c|}{$49(98 \%)$} & $\begin{array}{c}0.2^{1}, \mathbf{0 . 0 0 0 1}^{\mathbf{2}} \\
\mathbf{0 . 0 0 1}^{3}\end{array}$ \\
\hline$P 65$ & 7 & 12 & 11 & - & 3 & 5 & 10 & 2 & - & 3 & 17 & 30 & \\
\hline $\begin{array}{l}\text { Cases in } \\
\text { statistical } \\
\text { group (\%) }\end{array}$ & \multicolumn{2}{|c|}{$19(63.3 \%)$} & \multicolumn{2}{|c|}{$11(36.7 \%)$} & \multicolumn{2}{|c|}{$8(40 \%)$} & \multicolumn{2}{|c|}{$12(60 \%)$} & \multicolumn{2}{|c|}{$3(6 \%)$} & \multicolumn{2}{|c|}{47 (94\%) } & $\begin{array}{c}0.1^{1}, \mathbf{0 . 0 0 0 1}^{2} \\
\mathbf{0 . 0 0 1}^{3}\end{array}$ \\
\hline$c-R e l$ & 2 & 14 & 10 & 4 & - & 3 & 11 & 6 & - & - & 13 & 37 & \\
\hline $\begin{array}{l}\text { Cases in } \\
\text { statistical } \\
\text { group (\%) }\end{array}$ & \multicolumn{2}{|c|}{$16(53.3 \%)$} & \multicolumn{2}{|c|}{$14(46.7 \%)$} & \multicolumn{2}{|c|}{$3(15 \%)$} & \multicolumn{2}{|c|}{$17(85 \%)$} & \multicolumn{2}{|c|}{$0(0 \%)$} & \multicolumn{2}{|c|}{$50(100 \%)$} & $\begin{array}{c}0.008^{1}, \\
0.0001^{2}, 0.02^{3}\end{array}$ \\
\hline RelB & 2 & 5 & 14 & 9 & 1 & 4 & 12 & 3 & 1 & 2 & 22 & 25 & \\
\hline $\begin{array}{l}\text { Cases in } \\
\text { statistical } \\
\text { group (\%) }\end{array}$ & \multicolumn{2}{|c|}{$7(23.3 \%)$} & \multicolumn{2}{|c|}{$23(76.7 \%)$} & \multicolumn{2}{|c|}{$5(25 \%)$} & \multicolumn{2}{|c|}{$15(75 \%)$} & \multicolumn{2}{|c|}{$3(6 \%)$} & $47(9$ & & $\begin{array}{l}0.03^{2} \\
\mathbf{0 . 0 3}^{3}\end{array}$ \\
\hline$c-m y c$ & 1 & 8 & 15 & 6 & - & 2 & 11 & 7 & - & - & 12 & 38 & $0.1^{1}$ \\
\hline $\begin{array}{l}\text { Cases in } \\
\text { statistical } \\
\text { group (\%) }\end{array}$ & $9(30$ & & $21(70$ & & & $0 \%)$ & $18(7$ & & & & $50(1$ & & $\begin{array}{c}\mathbf{0 . 0 0 0 1}{ }^{2} \\
0.07^{1}\end{array}$ \\
\hline$P 27$ & 2 & 5 & 13 & 10 & 2 & 5 & 7 & 6 & 9 & 20 & 18 & 3 & \\
\hline $\begin{array}{l}\text { Cases in } \\
\text { statistical } \\
\text { group (\%) }\end{array}$ & $7(23$. & $3 \%)$ & $23(76$ & & & $5 \%)$ & $13(6$ & & & $8 \%)$ & $21(4$ & & $0.002^{2}$, \\
\hline
\end{tabular}

Arbitrary level of expression in immunoblotting: Nil/not detectable (-); Weak (+); Moderate (++); Strong (+++). p-value obtained by probability Fisher's (exact) test using Graph Pad Instat 6.0 comparing the expression of proteins (nil + weak Vs moderate + strong) among ${ }^{1}$ Control Vs Precancer, ${ }^{2}$ Control Vs Cancer, ${ }^{3}$ Precancer Vs cancer, ${ }^{4} \mathrm{HPV}{ }^{+v e}$ cancer Vs HPV ${ }^{-v e}$ cancer. $p$-values $\leq 0.05$ are considered as statistically significant. $\mathrm{ns}=$ not significant.

Table 1D: Expression of NF-kB family members between HPV16 ${ }^{+v e}$ and HPV ${ }^{-v e}$ tongue cancer cases

\begin{tabular}{|c|c|c|c|c|c|c|c|c|c|}
\hline \multirow{3}{*}{$\begin{array}{l}\text { Target proteins }(\downarrow) \\
\text { Expression level } \\
(\rightarrow)\end{array}$} & \multicolumn{8}{|c|}{ Total TSCC $(n=50)$} & \multirow{3}{*}{ p-value } \\
\hline & \multicolumn{4}{|c|}{ HPV16 positive TSCC $(n=14)$} & \multicolumn{4}{|c|}{ HPV negative TSCC $(n=36)$} & \\
\hline & $\begin{array}{c}\text { Nil } \\
-\end{array}$ & $\begin{array}{c}\text { Weak } \\
+\end{array}$ & $\begin{array}{c}\text { Moderate } \\
++\end{array}$ & $\begin{array}{c}\text { Strong } \\
++++\end{array}$ & $\begin{array}{c}\text { Nil } \\
-\end{array}$ & $\begin{array}{c}\text { Weak } \\
+\end{array}$ & $\begin{array}{c}\text { Moderate } \\
++\end{array}$ & $\begin{array}{c}\text { Strong } \\
++++\end{array}$ & \\
\hline P50 & - & 1 & 2 & 11 & - & 1 & 12 & 23 & $0.4^{4}(\mathrm{~ns})$ \\
\hline $\begin{array}{l}\text { Cases in statistical } \\
\text { group (\%) }\end{array}$ & \multicolumn{2}{|c|}{$1(7.1 \%)$} & \multicolumn{2}{|c|}{$13(92.9 \%)$} & \multicolumn{2}{|c|}{$1(2.7 \%)$} & \multicolumn{2}{|c|}{$35(91.3 \%)$} & \\
\hline $\begin{array}{l}P 52 \\
-\end{array}$ & & 1 & 3 & 10 & - & - & 17 & 19 & $0.2^{4}(\mathrm{~ns})$ \\
\hline $\begin{array}{l}\text { Cases in statistical } \\
\text { group (\%) }\end{array}$ & \multicolumn{2}{|c|}{$1(7.1 \%)$} & \multicolumn{2}{|c|}{$13(92.9 \%)$} & \multicolumn{2}{|c|}{$0(0 \%)$} & \multicolumn{2}{|c|}{$36(100 \%)$} & \\
\hline$P 65$ & - & 1 & 2 & 11 & - & 2 & 15 & 19 & $1.00^{4}(\mathrm{~ns})$ \\
\hline
\end{tabular}




\begin{tabular}{|c|c|c|c|c|c|c|c|c|}
\hline $\begin{array}{l}\text { Cases in statistical } \\
\text { group (\%) }\end{array}$ & $1(7.1 \%)$ & \multicolumn{2}{|c|}{$13(92.9 \%)$} & \multicolumn{2}{|c|}{$2(5.5 \%)$} & \multicolumn{2}{|c|}{$34(94.5 \%)$} & \multirow[b]{2}{*}{$1.00^{4}(\mathrm{~ns})$} \\
\hline$c-R e l$ & - & 4 & 10 & - & - & 9 & 27 & \\
\hline $\begin{array}{l}\text { Cases in statistical } \\
\text { group (\%) }\end{array}$ & $0(0 \%)$ & \multicolumn{2}{|c|}{$14(100 \%)$} & \multicolumn{2}{|c|}{$0(0 \%)$} & \multicolumn{2}{|c|}{$36(100 \%)$} & \\
\hline RelB & - & 6 & 7 & 1 & 1 & 16 & 18 & $1.00^{4}(\mathrm{~ns})$ \\
\hline $\begin{array}{l}\text { Cases in statistical } \\
\text { group (\%) }\end{array}$ & $1(7.1 \%)$ & \multicolumn{2}{|c|}{$13(92.9 \%)$} & \multicolumn{2}{|c|}{$2(5.5 \%)$} & \multicolumn{2}{|c|}{$34(94.5 \%)$} & \\
\hline$c-m y c$ & - & 8 & 6 & - & - & 4 & 32 & $1.00^{4}(\mathrm{~ns})$ \\
\hline $\begin{array}{l}\text { Cases in statistical } \\
\text { group (\%) }\end{array}$ & $0(0 \%)$ & \multicolumn{2}{|c|}{$14(100 \%)$} & \multicolumn{2}{|c|}{$0(0 \%)$} & \multicolumn{2}{|c|}{$36(100 \%)$} & \\
\hline$P 27$ & 2 & 5 & 3 & 7 & 16 & 13 & - & $0.14^{4}(\mathrm{~ns})$ \\
\hline $\begin{array}{l}\text { Cases in statistical } \\
\text { group (\%) }\end{array}$ & $6(42.8 \%)$ & \multicolumn{2}{|c|}{$8(51.2 \%)$} & \multicolumn{2}{|c|}{$23(63.8 \%)$} & \multicolumn{2}{|c|}{$13(36.2 \%)$} & \\
\hline
\end{tabular}

Arbitrary level of expression in immunoblotting: Nil/not detectable (-); Weak (+); Moderate $(++)$; Strong $(+++)$. $p$-value obtained by probability Fisher's (exact) test using Graph Pad Instat 6.0 comparing the expression of proteins (nil + weak Vs moderate + strong) among $\mathrm{HPV}^{+v e}$ cancer Vs HPV-ve cancer. $p$-values $\leq 0.05$ are considered as statistically significant. ns $=$ not significant.

inhibitory effect of Fra-2-siRNA on the expression of c-Rel in TSCC cells. As shown in Figure 5C, 5D, Fra-2siRNA at $80 \mathrm{nM}$ concentration dramatically reduced the level of c-Rel expression in TSCC cells. It shows a clear cross-talk between NF- $\mathrm{kB} / \mathrm{c}-$ Rel and AP-1/Fra-2. The knockdown efficiency determined by western blotting demonstrated $\sim 90 \%$ suppression of c-Rel and Fra-2 in both $\mathrm{HPV}^{+\mathrm{ve} / \mathrm{ve}}$ cell lines (Figure 5A-5D, upper panel).

\section{Knocking down of c-Rel reduced invasive and migration property of tongue cancer cells}

To examine the efficiency of c-Rel silencing on the invasive properties of both $\mathrm{HPV}^{+/-v e} \mathrm{TSCC}$ cells, we performed matrigel invasion assay (Figure 6A, 6B) using standard procedure [6]. The results demonstrated that the invasion of both $\mathrm{HPV}^{+v e}$ and $\mathrm{HPV}^{-\mathrm{ve}}$ cells was significantly reduced after c-Rel silencing when compared with invasion of untreated or scrambled siRNA treated cells (Figure 6A, 6B). Interestingly, c-Rel silencing at $120 \mathrm{nM}$ of concentration was more effective in $\mathrm{HPV}^{+\mathrm{ve}}$ (UPCI:SCC090) (Figure 6A) cells as compared with $\mathrm{HPV}^{-\mathrm{ve}}$ (AW13516) cells (Figure 6B). Quantitation of the invading $\mathrm{HPV}^{+v e}$ cells showed only $37 \%$ ( \pm 32 cells, $p=0.001)$ when compared to untreated $( \pm 85.6$ cells; $100 \%)$ or scrambled siRNA treated cells ( \pm 77 cells; $89.9 \%)$ (Figure 6A). But $\mathrm{HPV}^{-\mathrm{ve}}$ cells showed 48.5\% ( \pm 84.3 cells, $p=0.008$ ) invasion after c-Rel siRNA treatment as compared to untreated ( \pm 173.6 cells, $100 \%)$ or scrambled treated groups $( \pm 143.6$ cells; $82.6 \%)$ (Figure $6 \mathrm{~B})$. The untreated groups served as negative control and scrambled siRNA treated was considered as treated controls for both the cell lines.

To further demonstrate that the change in migration ability to accelerate the closure of a wound after c-Rel inhibition in TSCC cells, wound assay was performed after silencing of c-Rel in both AW13516 (HPV $\left.{ }^{-v e}\right)$ and UPCI:SCC090 (HPV16 $6^{\text {+ve }}$ ) cells. The results revealed that c-Rel silencing for 18 hours in $\mathrm{HPV}^{- \text {ve }}$ cells showed $\sim 53 \%$ migration when compared to untreated or scrambled treated control cells that showed $\sim 100 \%$ and 99\% migration respectively (Figure 6C). Interestingly, c-Rel knockdown in HPV16 $6^{+v e}$ cells showed only $\sim 22 \%$ migration at 18 hours while untreated or scrambled treated cells showed $\sim 45 \%$ and $\sim 43 \%$ migration rate respectively (Figure 6D). These results together well correlate with the significant reduction in cell invasion and migration after knocking down c-Rel in both $\mathrm{HPV}^{+/-v e}$ tongue cancer cells.

\section{String analysis of $\mathrm{NF}-\kappa \mathrm{B}$ indicates intricate interactive network and signalling pathways of c-Rel}

We used search tool for the retrieval of interacting genes (STRING) server analysis to identify possible physical and functional network of NF- $\mathrm{kB}, \mathrm{AP}-1$ and their downstream target genes and signalling pathways and it revealed involvement of high-degree (combined score of 0.7) hub genes in the local network (Figure 7). We found that inhibition of c-Rel by c-Rel siRNA reduces the expression level of p52, RelB, c-myc, c-Jun and Fra-2 as shown in the results indicating thereby that c-Rel transcriptionally regulate these genes. In addition, c-Rel also physically interacts with the products of c-Jun, c-myc, Fra-2. It indicates c-Rel forms a transcriptional network (Figures 4C-4E and 5A-5D) as well as proteinprotein interaction network (Figure 7). A number of NF- $\kappa B$ subunits physically interact with other signalling molecules, as indicated by STRING pathway analysis (Figure 7), include those genes whose expression has 
been altered after c-Rel knockdown, suggesting the fact that c-Rel transcriptionally regulates numerous essential genes that might play a critical role during tongue carcinogenesis.

\section{DISCUSSION}

Present study examines the biological as well as clinical consequences of HPV infection and raises question as to how NF- $\kappa \mathrm{B}$ plays a role in the aggressive tongue tumorigenesis. It also raises question whether there exists patho-physiological differences between $\mathrm{HPV}^{+\mathrm{ve}}$ and $\mathrm{HPV}^{-}$ ve tumors contributing towards differential tumorigenicity and treatment outcome. Epidemiologic studies [4, 6, 25-28] including recent mutational landscape analysis of head and neck carcinoma have demonstrated a significant difference between $\mathrm{HPV}^{+\mathrm{ve}}$ and $\mathrm{HPV}^{-\mathrm{ve}}$ tumors [29]. The overall mutation rate was found to be almost two times higher in highly aggressive $\mathrm{HPV}^{-\mathrm{ve}}$ tumors than that of $\mathrm{HPV}^{+\mathrm{ve}}$ HNSCCs [30-32]. It is intriguing to find that the majority $(94.4 \%)$ of $\mathrm{HPV}^{-\mathrm{ve}}$ patients were tobacco smokers/ chewers and/or alcohol users while HPV infection was found mainly in non-tobacco users $(75 \%)$. It indicates that tobacco can inhibit HPV persistence in the oral cavity rather smoking protects from HPV infection possibly because of toxic effects and oxidative stress created by nicotine and/ or alcohol. This is clear from our results that $8(80 \%)$ out of 10 female TSCC patients were $\mathrm{HPV}^{+\mathrm{ve}}$ and $75 \%(6 / 8)$ of them were non-smokers. In contrast, out of 40 male TSCC patients, all were tobacco smokers but only $6(15 \% ; 6 / 40)$ were $\mathrm{HPV}^{+\mathrm{ve}}$ and $85 \%$ were $\mathrm{HPV}^{-\mathrm{ve}}$ (Table $1 \mathrm{~A}$ ). Thus, there is a distinct difference between $\mathrm{HPV}^{+\mathrm{ve}}$ and $\mathrm{HPV}^{-\mathrm{ve}}$
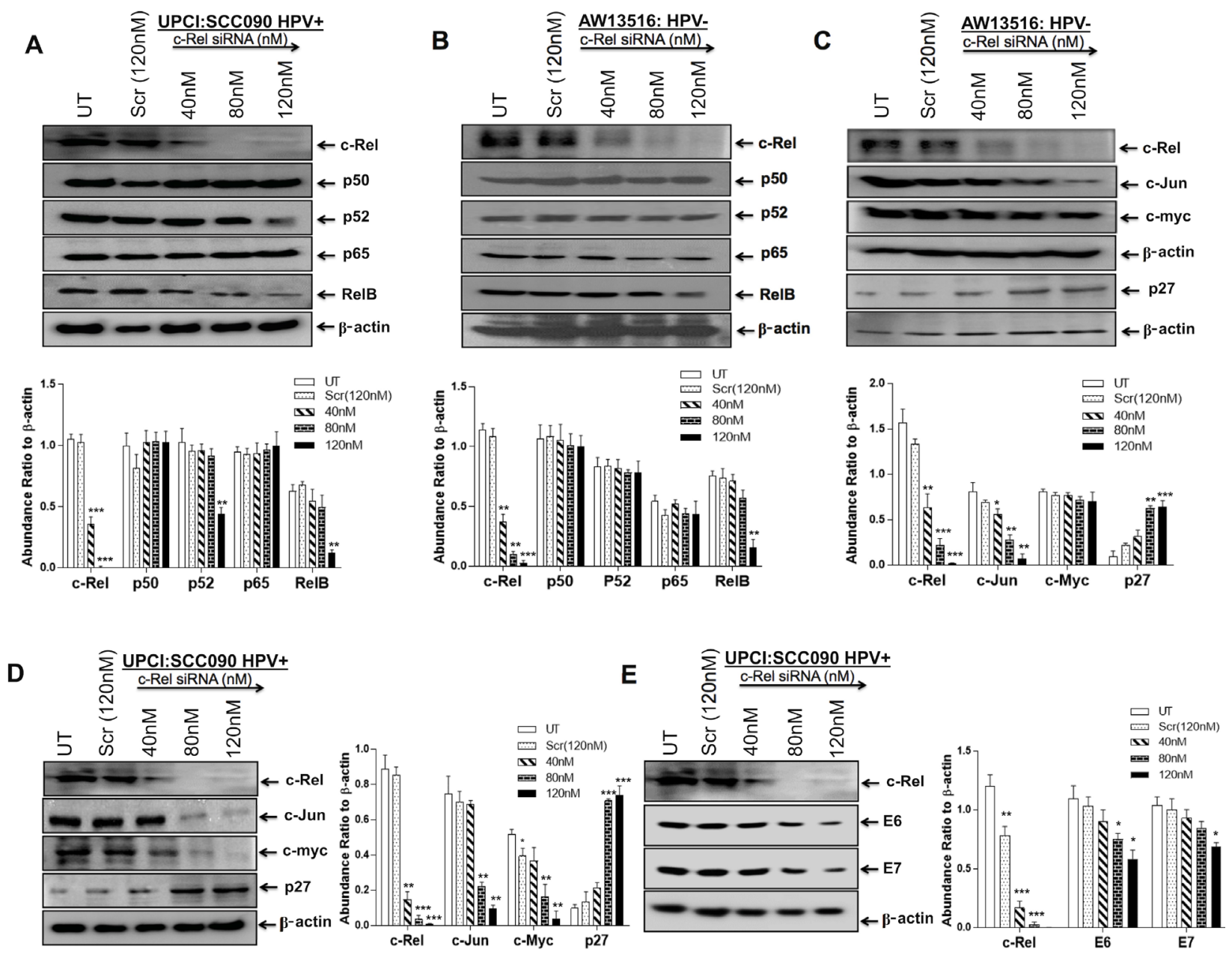

Figure 4: (A-E) Knocking down of c-Rel by specific siRNA in HPV ${ }^{\text {tve }}$ and HPV ${ }^{\text {-ve }}$ TSCC cells. Representative immunoblots (Panel A, B) showing complete inhibition of c-Rel expression at the concentration of $80 \mathrm{nM}-120 \mathrm{nM}$ in both UPCI:SCC090; HPV16 ${ }^{+\mathrm{ve}}$ (A) and AW13516; HPV-ve cells (B). $40 \mu \mathrm{g}$ cellular proteins isolated from both the cell lines following treatment with c-Rel-siRNA(40 nM-120 nM) and scrambled siRNA $(120 \mathrm{nM})$ as control for 48 hours were examined for its effects on c-Rel and other NF- $\mathrm{kB}$ family proteins (A and B) and also on their targets; c-myc, c-Jun and p27 (C, D) and HPV16 E6/E7 oncogenes (E). To ensure equal loading of protein, $\beta$-actin was used as an internal control. Quantitation of bands was performed by densitometric analysis. Significant $(p<0.05)$ when compared with untreated control vs. siRNA treated group. The data in corresponding bar diagram are expressed as the mean \pm SD of three independent experiments. ${ }^{*} p<0.05,{ }^{* *} p<0.01 \&{ }^{* * *} p<0.001$. 
tumors, $\mathrm{HPV}^{-\mathrm{ve}}$ or tobacco associated tumors being both clinically and genomically at greater risk than the $\mathrm{HPV}^{+v e}$ for aggressive tumorigenesis and worst prognosis [33].

Analysis of HPV and their genotyping demonstrated $28 \%(14 / 50)$ exclusive prevalence $(100 \%)$ of HR-HPV type 16 , the majority $(78.6 \%)$ of which were found in well differentiated tumors. In oral cancer, we were the first to demonstrate that well differentiated tumors induced by HPV infection as revealed by predominance of well stained koilocytes showed better prognosis when treated [12]. We also demonstrated that HPV infection promotes selective overexpression and regular participation of p65 in functional NF- $\mathrm{NB}$ complex formation leading to transactivation of p16, p21 and p27 genes involved in cell proliferation and differentiation [12], which has been later confirmed by several authors in HNSCCs [4, 6, 25-28].

Since infection, inflammation and cancer are intimately linked, the pro-inflammatory transcription
A
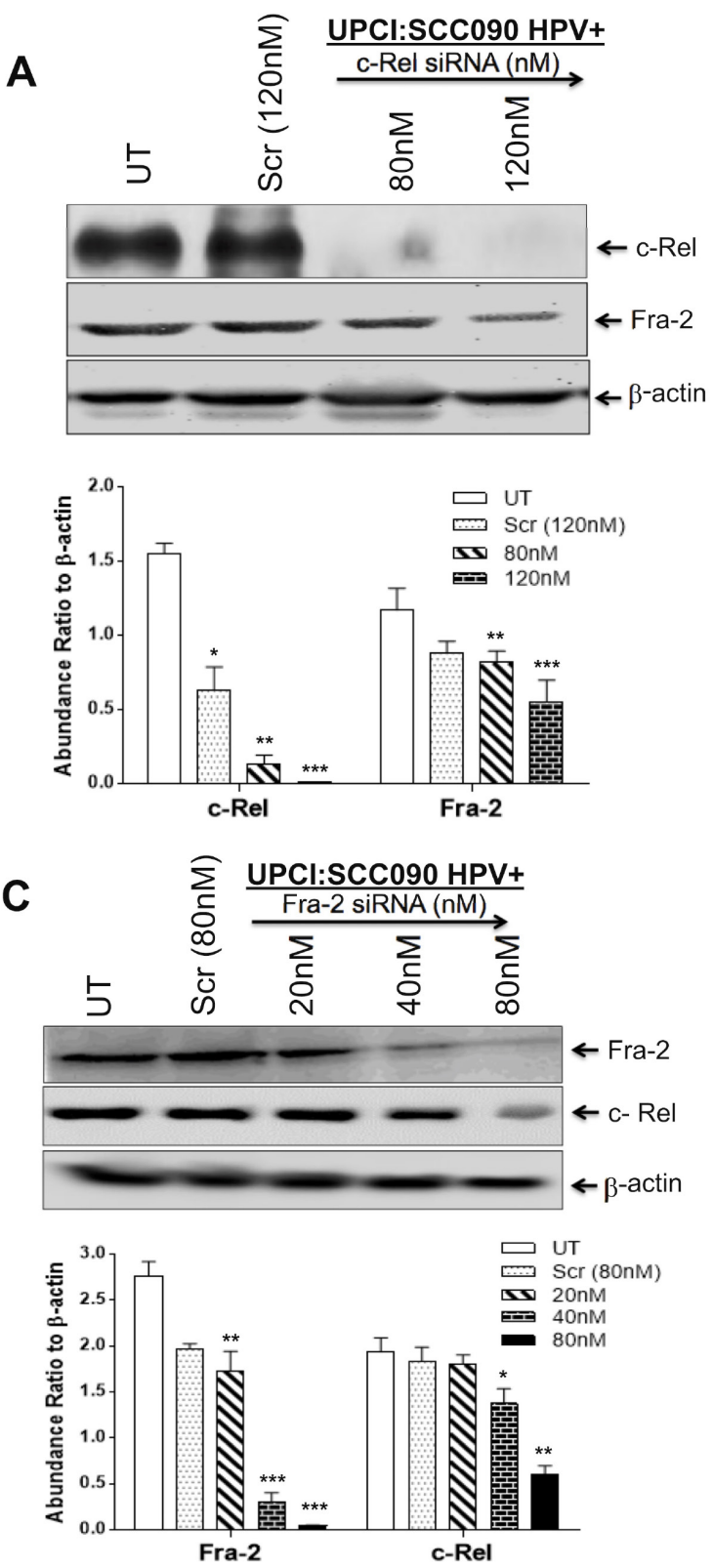

B
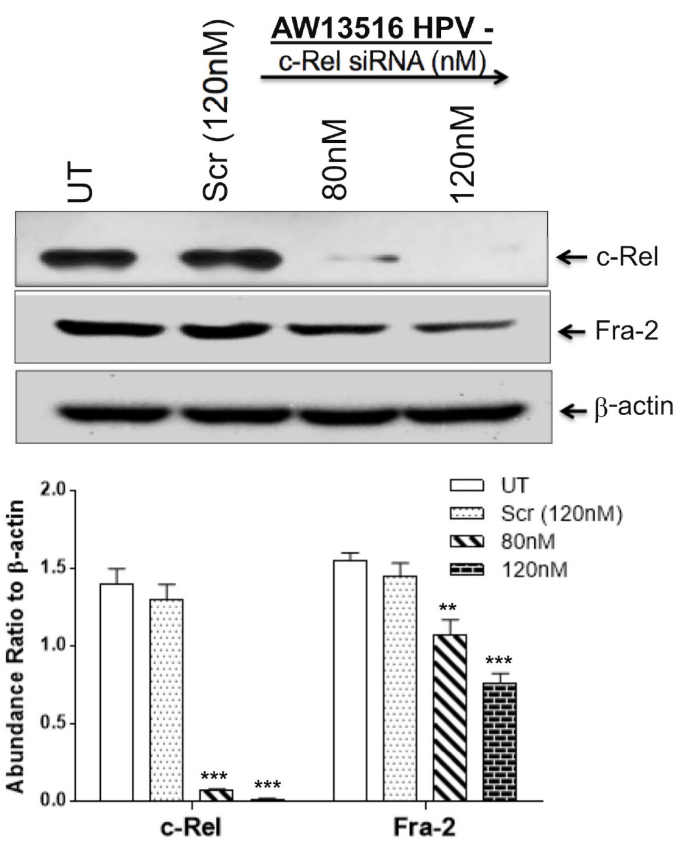

D
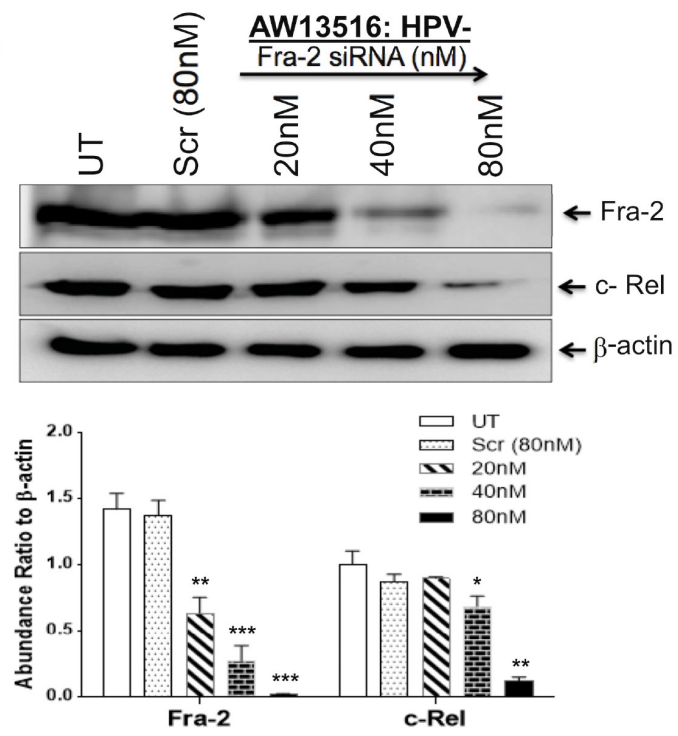

Figure 5: (A-D) AP-1/Fra-2 and NF- $\mathrm{kB} / \mathrm{c}-$ Rel specific silencing altered the expression of c-Rel and Fra-2 in both $\mathrm{HPV}^{+\mathrm{ve}}$ and $\mathrm{HPV}^{-\mathrm{ve}}$ TSCC cells. siRNA knockdown efficiencies were analysed by western blotting (A-D upper panel). c-Rel siRNA at $120 \mathrm{~nm}$ of concentration reduced the expression of Fra-2 in both $\mathrm{HPV}^{+\mathrm{ve}}(\mathrm{A})$ and $\mathrm{HPV}^{-v e}(\mathrm{~B}) \mathrm{TSCC}$ cells. C, D show reduction in the expression of c-Rel in both $\mathrm{HPV}^{+\mathrm{ve}}(\mathrm{C})$ and $\mathrm{HPV}^{-\mathrm{ve}}$ (D) TSCC cells following $80 \mathrm{nM}$ of Fra-2 siRNA. Equal loading of protein was checked by using $\beta$-actin as internal control. Quantitation of bands was performed by densitometric analysis and are shown in corresponding bar diagrams. Significant $(p<0.05)$ when compared with untreated control vs. treated group. The data in bar diagram are expressed as the mean $\pm \mathrm{SD}$ of three independent experiments. ${ }^{*} p<0.05 \&{ }^{* *} p<0.01$. 
factor, NF- $\mathrm{KB}$ is always constitutively activated and overexpressed in almost all cancers [12, 15, 19, 21, 22, 34]. In TSCC, NF- $\mathrm{kB}$ also show high DNA binding activity and differential overexpression of NF- $\mathrm{KB}$ proteins in majority of cases. We observed a slightly lower DNA binding activity of NF-kB in HPV16 ${ }^{+v e}$ TSCCs. Gel supershift assays revealed p50 as the major DNA binding partner $(\sim 90 \%)$ in both $\mathrm{HPV}^{+v e}$ and $\mathrm{HPV}^{-v e}$ tumors and a small but distinct participation of c-Rel ( $15-25 \%)$ was found in majority of $\mathrm{HPV}^{-\mathrm{ve}}$ tumors. These HPV-ve TSCCs showed either p50-p50 homo-dimer or heterodimer of p50-c-
Rel $(41 / 50 ; 82 \%)$ in the formation of functional NF- $\mathrm{KB}$ complex mainly in advanced stage poorly or moderately differentiated tumors. This is well corroborated with the western blotting results showing significantly higher expression of c-Rel in HPV-negative tumors and cell lines (Figure 3A, 3B). Overexpression of p50 and c-Rel proteins have been reported in variety of solid tumors and hematopoietic cancer $[12,15,21,35,36]$. It implies that these two proteins have the potential to induce aggressive tumorigenic phenotype and metastasis as reported by other authors [21-23, 37, 38]. c-Rel was also shown to be highly
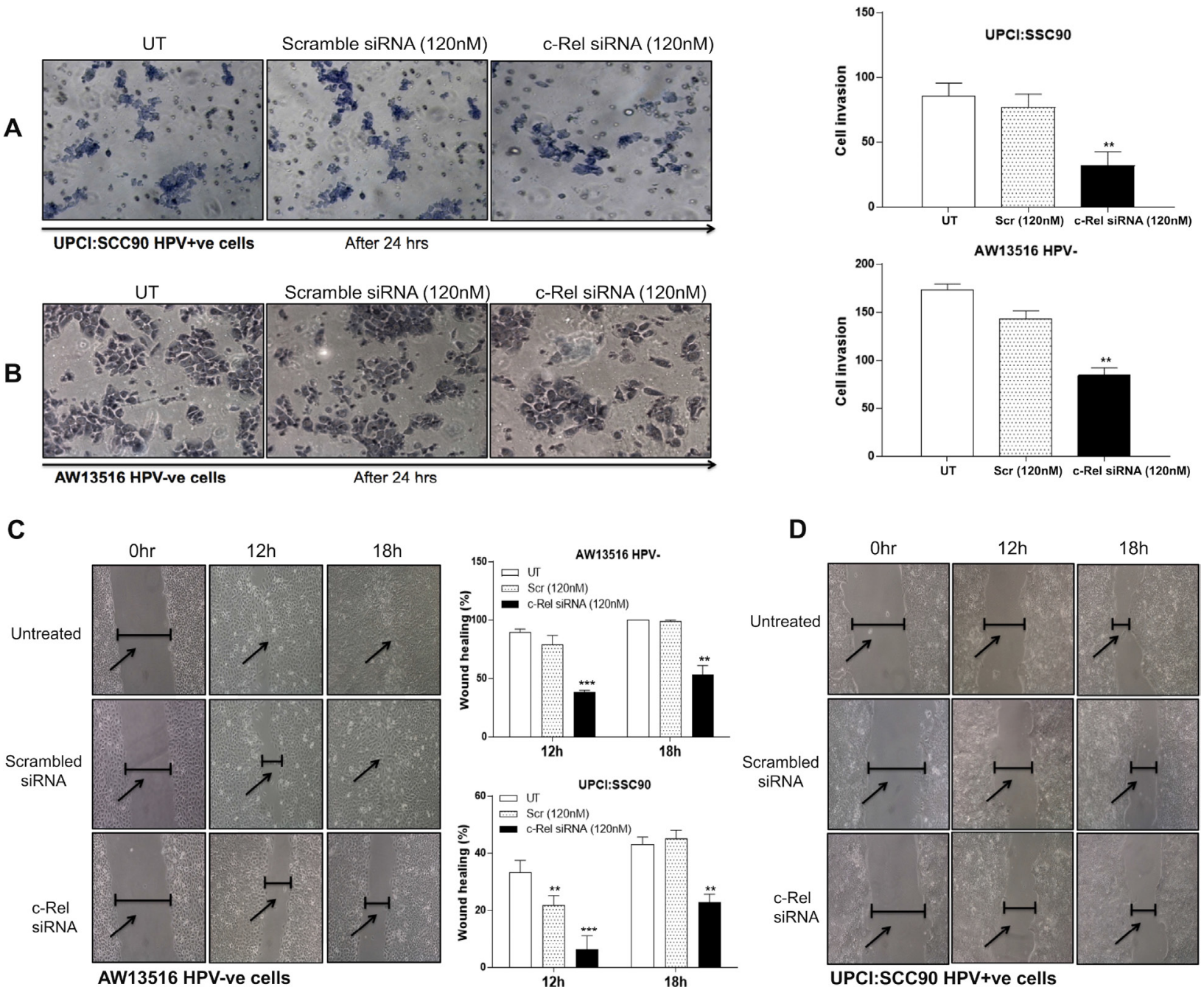

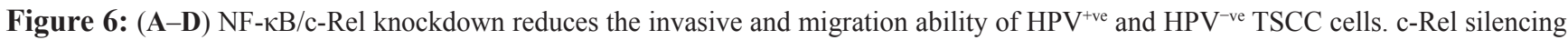
by specific siRNA leads to alteration in invasion property in both $\mathrm{HPV}^{+\mathrm{ve}}$ (A) and $\mathrm{HPV}^{-\mathrm{ve}}$ (B) TSCC cells. A matrigel transwell invasion assay was used to evaluate the migration ability of untreated, scrambled siRNA and c-Rel-siRNA treated TSCC cells. Equal number of cells $\left(1 \times 10^{5}\right)$ was seeded in the matrigel coated upper chamber. After 24 hours of incubation at $37^{\circ} \mathrm{C}$ and $5 \% \mathrm{CO}_{2}$, the cells that invaded through the membrane were fixed and stained with Giemsa, and images were captured using inverted microscope. Representative fields of view for each well are shown (A, B). Cell invasion was quantified by counting cells from six random fields. Panel C, D: Scratch assay after c-Rel silencing demonstrated that cell migration was dramatically decreased in experimental groups after c-Rel siRNA transfection compared with untreated and scrambled treated control groups. Inverted microscope images of wound closure at 0 hour, 12 hours and 18 hours in AW13516 (C) and UPCI:SCC090 (D) cells are indicated. Migration rate was calculated by image J software. The data in corresponding bar diagram are expressed as the mean $\pm \mathrm{SD}$ of three independent experiments. ${ }^{*} p<0.05,{ }^{* *} p<0.01,{ }^{* * *} p<0.001 \&{ }^{* * * *} p<0.0001$. 
overexpressed in aggressive breast cancer [21], leukemias/ lymphomas and in pancreatic ductal adenocarcinomas [22]. Together these findings strongly support activation of $\mathrm{NF}-\kappa \mathrm{B}$ with selective participation of c-Rel with p50 may play a critical role in inducing aggressive tumorigenesis specifically in $\mathrm{HPV}^{-\mathrm{ve}}$ and poorly differentiated TSCC patients with tobacco habits who show worst prognosis.

Interestingly, $\mathrm{HPV}^{16} 6^{+\mathrm{ve}}$ TSCCs and cell lines (UPCI:SCC090) showed selective participation of p65 along with p50-c-Rel complex in majority (78.6\%) of well differentiated tumors. Only three (21.4\%) HPV16 $6^{\text {+ve }}$ TSCC cases showed composition of p50-c-Rel but they were poorly or moderately differentiated tumors. It is therefore suggested that the involvement of p65 in $\mathrm{NF}-\kappa \mathrm{B}$ complex appears to be induced by HPV which is responsible for well differentiation of TSCC [12]. The minor but selective participation of c-Rel in DNA binding activity and its higher expression at mRNA and protein level in majority of TSCCs are indicative of its critical role in aggressiveness of the disease even it may not involve in DNA binding activity [12]. Furthermore, since cytokines or chemokines such as monocyte chemoattractant protein-1 (MCP-1) is differentially regulated in HPV16 positive cervical cancer, it would be highly interesting to look for expression of these chemokines being affected by altered NF- $\kappa \mathrm{B}$ composition between $\mathrm{HPV}^{+\mathrm{ve}}$ and $\mathrm{HPV}^{-\mathrm{ve}}$ TSCCs [39, 40].

We also observed higher expression of c-myc and c-Jun which in conjunction with $\mathrm{NF}-\kappa \mathrm{B}$ proteins are known to play critical role in cellular transformation and metastasis [41-44]. The promoter region of NF- $\kappa \mathrm{B} / \mathrm{c}-\mathrm{Rel}$ contains c-Jun and c-myc binding sites and a direct evidence has been provided for the critical role of c-Rel in aggressive breast carcinogenesis. These authors generated transgenic mice that overexpressed c-Rel in the mammary gland and more than $30 \%$ of these mice developed one or more mammary tumors. Thus, activation of c-Rel appears to induce expression of cyclin D1, c-Myc, and Bcl-xL that promote tumor growth.

Recently, we have shown overexpression and selective DNA binding activity of c-Jun with Fra-2 induced poor differentiation, aggressive tumor behaviour

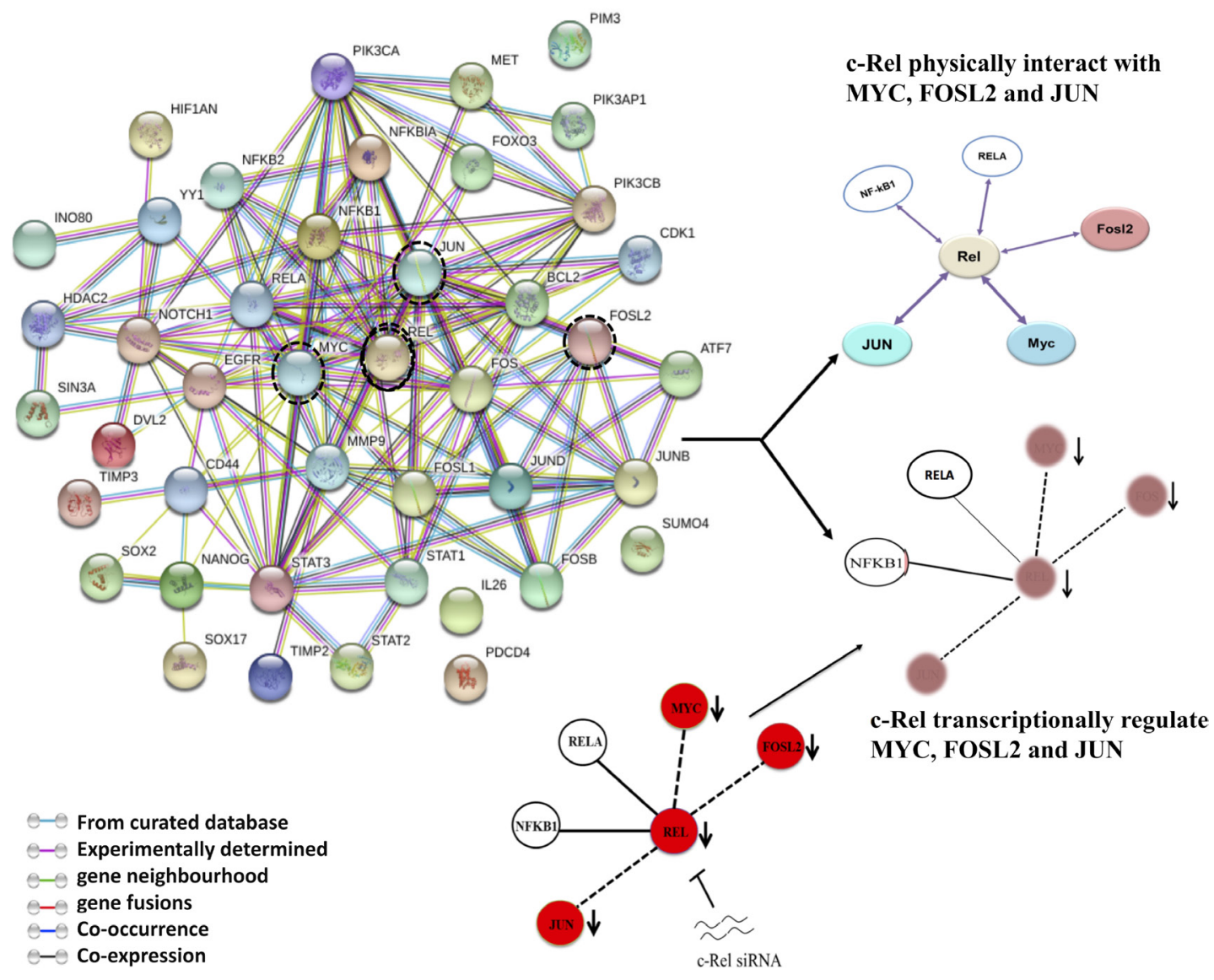

Figure 7: String network of NF-кB showing interactive pathways of c-Rel. A cancer-associated protein-protein interaction (PPI) network of NF- $\kappa B$ was constructed using STRING server on the basis of highest confidence (score $>0.7$ ). c-Rel knockdown reduces the levels of p52, RelB, c-Jun, c-myc and Fra-2 as shown in the results indicating thereby that c-Rel transcriptionally regulate these genes. c-Rel also physically interacts with the products of c-Jun, c-myc, Fra-2 indicating c-Rel forms both transcriptional network as well as protein-protein interaction network. 
and metastasis specifically in HPV ${ }^{-v e}$ TSCCs [6]. c-Jun is known to involve in aggressive tumor phenotype and metastasis in many cancers $[43,45,46]$ and c-myc is also shown to increase the expression of Cyclin D1 and decrease expression of p21, p27 and p53 leading to proliferative advantage of cancer cells [47-49]. It has been shown that c-Rel can induce activation of c-myc, c-Jun, CDKs and decrease p27Kip1, causing increased cell proliferation and aggressive tumor phenotype [49-51]. Our cell invasion and migration assays demonstrated that c-Rel silencing can remarkably reduced invasion and migration capability of both $\mathrm{HPV}^{+\mathrm{ve}}$ and $\mathrm{HPV}^{-\mathrm{ve}}$ tongue cancer cells (Figure 6A-6D). These results together indicate potential role of $\mathrm{c}-\mathrm{Rel}$ in inducing invasion and metastasis.

All these observations put together, a model (see Figure 8) has been proposed to indicate how NF- $\mathrm{B}, \mathrm{AP}-1$ and other associated genes involved during development, progression and prognosis of oral tongue cancer involving signalling pathways and interactions following exposure to potential risk factors; environment, tobacco, alcohol, viral (HPV) and/or bacterial infections. It suggests an essential functional regulatory role of AP-1 and NF- $\mathrm{NB}$ in tongue carcinogenesis both in presence or absence of HPV infection (Figure 8). Aberrant activation/expression of AP-1/Fra-2 and NF- $\mathrm{BB} / \mathrm{c}-$ Rel was observed in most aggressive poorly differentiated tongue cancer with worst prognosis and the specific siRNA based silencing of c-Rel or Fra-2 further strengthened the functional role of c-Rel and Fra-2 and their possible cross-talk and interaction with other critical genes during aggressive tongue carcinogenesis.

A functional NF- $\kappa \mathrm{B}$ binding site has been reported in upstream regulatory region (URR) of HPV16 that controls HPV oncogene transcription [52]. c-Rel mediated control of HPV transcription could be due to its target gene c-Jun which forms a part of functionally active AP-1, essential for HPV transcription. In turn, HPV E7 has been shown to attenuate NF- $\kappa \mathrm{B}$ activation together with

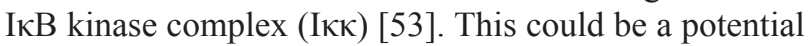

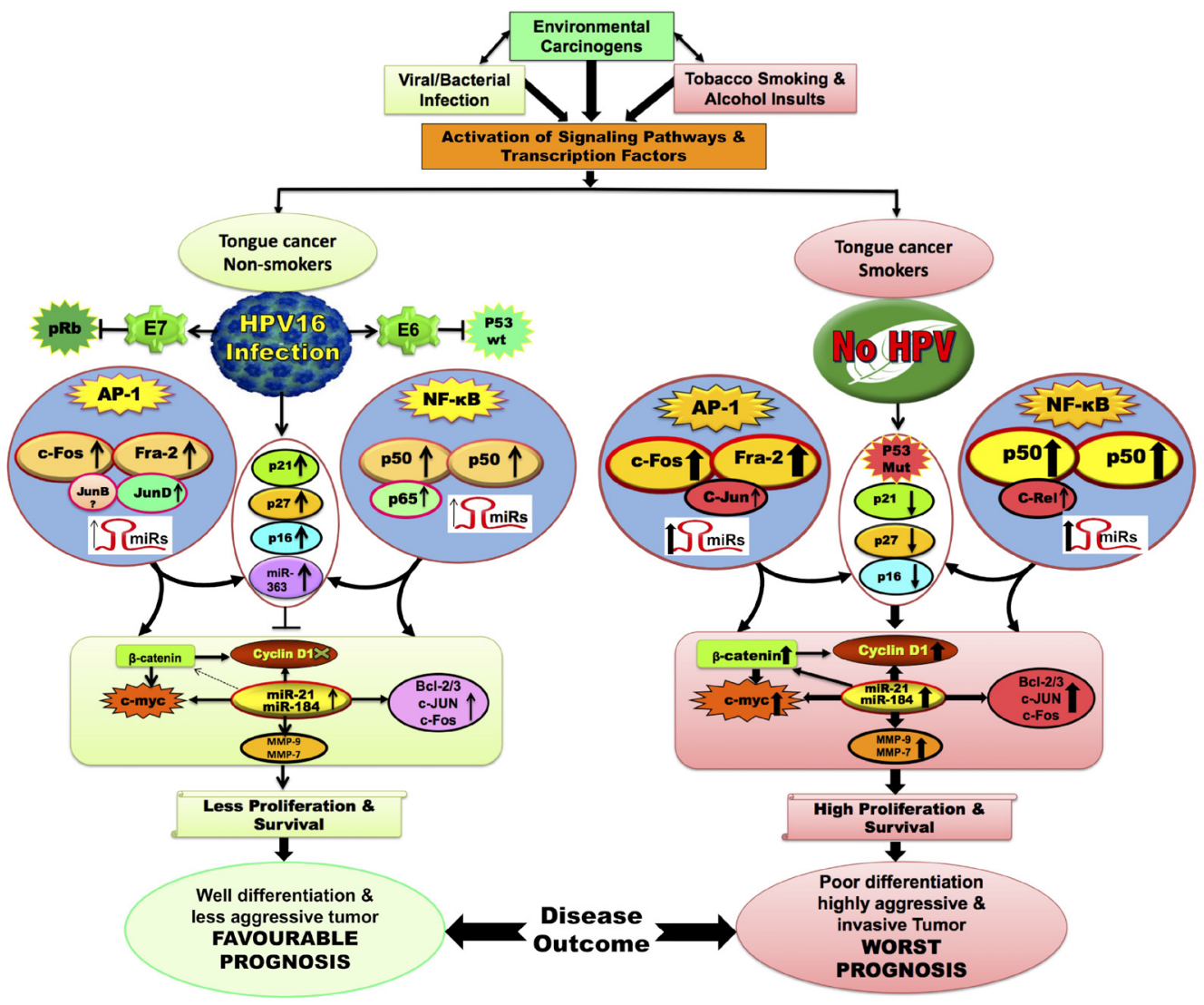

Figure 8: Schematic model showing the possible mechanism and cross-talk between NF- $\mathrm{B}$ and AP-1 with or without HPV infection during tongue carcinogenesis. Constitutive activation of AP-1; c-Fos/Fra-2 and NF- $\mathrm{kB}$; p50/c-Rel play a major role during aggressive tongue carcinogenesis. Selective activation of AP-1/c-Jun and NF- $\mathrm{B} / \mathrm{c}-\mathrm{Rel}$ in HPV negative/ advanced grades of TSCCs increases the expression of its target genes (MMP-9, Bcl-2, c-myc, CyclinD1, miR-21 \& miR-184) that may leads to poor differentiation and worst prognosis. Selective activation of AP-1/JunD and NF- $\mathrm{kB} / \mathrm{p} 65$ in DNA-binding activity in HPV16 positive TSCC presumably increased the expression of p21, p16 \& p 27 which might also be contributing to better differentiation in HPV16 positive TSCCs, who show good prognosis and better survival following treatment. 
reason for finding a comparatively reduced NF- $\kappa \mathrm{B}$ activity in $\mathrm{HPV}^{+\mathrm{ve}}$ TSCCs [22].

Earlier, we have demonstrated selective participation of c-Jun with Fra-2 led to poor differentiation and aggressive tumor phenotype mainly in $\mathrm{HPV}^{-v e}$ TSCCs [6]. We therefore wanted to further understand if there is any cross-talk between Fra-2 and c-Rel and for this we used Fra-2 specific siRNA and the results showed remarkable reduction in the expression of c-Rel in $\mathrm{HPV}^{+/-v e} \mathrm{TSCC}$ cells (Figure 5C, 5D), while c-Rel silencing inturn led to reduced expression of Fra-2 in both $\mathrm{HPV}^{+/-v e}$ cells however, it was more pronounced in $\mathrm{HPV}^{+v e}$ cells (Figure 5A, 5B). This is because Fra-2 contains transcription binding sites for c-Rel on its promoter region and we speculate that Fra2 might participate in modulating the expression of c-Rel through JNK/C-JUN pathway. c-Rel silencing reduced cell proliferation, invasion, and migration of TSCC cells and also inhibited expression of c-Jun, Fra-2 and c-myc.

In conclusion, it is suggested that both Fra-2 and c-Rel play essentially a critical role in the progression of TSCC specifically in HPV ${ }^{-v e}$ TSCC patients while HPV infection induces increased expression of p65 and p27 leading to well differentiation and better prognosis mainly in non-smoking TSCC patients.

\section{MATERIALS AND METHODS}

\section{Study subjects and collection of biological samples}

A total of 100 fresh tongue tissue biopsy specimens of different histopathological grades comprising precancer $(n=20)$, cancer $(n=50)$ along with adjacent normal controls $(n=30)$ were collected from the Department of ENT Surgery of Dr. Ram Manohar Lohia Hospital, New Delhi. None of these patients received any pre-operative radiation and chemotherapy. The clinico-pathological and epidemiological details of the patients were collected using standard proforma. Biopsy samples obtained immediately after surgery in sterile vials containing cold phosphate buffer saline (PBS), transported to lab on ice and stored in $-80^{\circ} \mathrm{C}$ deep freezer till further analysis.

Written informed consent was obtained from all the subjects prior to their inclusion in the study which was carried out in accordance with the principles of the Helsinki Declaration. The study was approved by the Institutional Ethics Committee of Dr. B. R. Ambedker, Center for Biomedical Research (ACBR), University of Delhi, Delhi, India, where the study was initially carried out.

\section{Cell lines and cell culture}

The two cell lines of tongue squamous cell carcinoma $\left(\mathrm{HPV}^{+\mathrm{ve}}\right.$ and $\left.\mathrm{HPV}^{-\mathrm{ve}}\right)$ were used in the present study. HPV16 ${ }^{\text {tve }}$ cell line, UPCI:SCC090 was derived from the base of tongue squamous cell carcinoma [54], a kind gift from Dr. Susanne M. Gollin, University of Pittsburgh, Pittsburgh, USA. The $\mathrm{HPV}^{-\mathrm{ve}}$ cell line, AW13516, a kind gift from Dr. M. M. Vaidya, ACTREC, Tata Memorial Hospital, Navi Mumbai, India was derived from squamous cell carcinoma of the human tongue [55]. Both cell lines were maintained in MEM and IMDM medium respectively, supplemented with $10 \%$ FBS and antibiotics at $37^{\circ} \mathrm{C}$ and $5 \% \mathrm{CO}_{2}$.

\section{Electrophoretic mobility shift assay (EMSA)}

EMSA was performed as described previously $[6,12]$. Briefly, $10 \mu \mathrm{g}$ of nuclear extract was incubated with $\gamma-{ }^{32} \mathrm{P}$-radiolabeled $\mathrm{NF}-\kappa \mathrm{B} \quad$ oligonucleotide (5'-AGTTGAGGGGACTTTCCCAGGGC-3') for $30 \mathrm{~min}$ in $25 \mu \mathrm{l}$ of reaction buffer. For the competition assay, $100 \times$ molar excess of unlabelled oligo $(\mathrm{NF}-\kappa \mathrm{B})$ and non-specific oligo (Oct-1) was added. ProteinDNA complexes were resolved in 6\% non-denaturing polyacrylamide gel and exposed to phosphorimager. For the supershift assay, $10 \mu \mathrm{g}$ nuclear extracts in reaction buffer were incubated with specific NF- $\kappa \mathrm{B}$ family protein antibodies (p50, p65, p52, c-Rel and RelB) for 60min at RT before the addition of radiolabeled probe $\left(\gamma-\mathrm{P}^{32}\right)$ and electrophoresis.

\section{Immunoblotting}

Protein isolated from all tumor tissues and cell lines $(40 \mu \mathrm{g} /$ lane) were separated on $8-15 \%$ SDS-PAGE. Immunoblotting was performed by the method described previously using specific antibodies (Supplementary Table 3) $[6,12]$. The NF-кB proteins expression level was quantitated on an arbitrary scale with respect to $\beta$-actin expression as strong $(+++)=>50 \%$; Medium $(++)=$ $10-50 \%$; Weak $(+)=<10 \%$ and nil/not detectable $(-)$ $=<1$ as described earlier.

\section{siRNA interference assay}

For c-Rel-siRNA interference assay, transient transfection of commercially available c-Rel and Fra-2 siRNA oligonucleotides (Santa Cruz, biotech, USA) was performed according to the manufacturer's protocol with minor modifications as described earlier [6].

\section{Matrigel invasion assay}

Invasion assay was performed to see the effect of c-Rel silencing on invasive characteristics of TSCC cells [6]. After 24 hours of c-Rel siRNA or scramble siRNA transfection at $120 \mathrm{nM}$ of concentration, TSCC cells were harvested and resuspended in FBS-free medium. A total of $1 \times 10^{5}$ cells were plated in upper chamber of the matrigelcoated transwell (Corning, USA). Medium with serum was added to the lower chamber as a chemoattractant. 
After incubation for 24 hours, cells on the lower surface of the membrane were fixed with formaldehyde followed by Giemsa staining. The images of migrated cells were acquired by an inverted microscope. The number of invaded cells was quantified by counting cells in five randomly selected fields under microscope. Comparisons were made between the untreated and/or scramble-siRNA treated and c-Rel knockdown wells. All experiments were performed in triplicates.

\section{Migration assay}

To investigate the migratory capacity of TSCC cells, cell scratch assay was performed. TSCC cells were transfected with $120 \mathrm{nM}$ c-Rel siRNA and control siRNA as described earlier [6] and incubated under standard conditions to achieve knockdown of c-Rel. After 24 hours, a scratch was carefully made by scraping through each well using a sterile pipette tip (200 ul). The cells were then washed, and scratches were monitored with an inverted microscope immediately after wounding and incubation at different time points. Images were taken exactly at the same position before and after the incubation and migration rate was calculated by using image $\mathrm{J}$ software.

\section{String analysis}

Protein-protein interactions (PPIs) were predicted using the STRING database v 9.1 (http://www.string-db. org/). Multiple cancer causing proteins were looked based on the following six criteria; neighbourhood, gene fusion, co-occurrence, co-expression, experimental evidence and existing databases [56].

\section{Statistical analysis}

The data analysis was performed using the statistical software Graph Pad Prism (version 6.0). The association between HPV infection and expression profile among different histopathological grades and clinico-pathological parameters in TSCC cases was determined using Fischer's exact test and student's $t$-test (two-tailed). The $p$ value $\leq 0.05$ was considered as statistically significant.

\section{Author contributions}

There is a total of 8 authors who have contributed in this study. SG and PK jointly participated in collection of samples, carrying out experiments, statistical data analysis, interpretation and initial writing of the manuscript. HK helped in monitoring experiments and critical reading of the manuscript. NS and SG senior ENT surgeons and pathologist who took biopsy and provided tissue samples, their histopathology and clinical details of the patients and critically reviewed the manuscript. DS monitored the study and critically reviewed the manuscript. ACB monitored the study, participated in the interpretation of data, drafting and critical reviewing of the manuscript. BCD conceptualized, designed and supervised the study, participated in data interpretation and critically reviewed, finalized and communicated the manuscript. All authors have read and approved the final manuscript.

\section{ACKNOWLEDGMENTS}

The authors thank Dr. Susanne M. Gollin (University of Pittsburgh, Pittsburgh, PA) and Dr. M. M. Vaidya, (ACTREC, Tata Memorial Hospital, Navi Mumbai, India) for kind gift of UPCI:SCC090 and AW13516 tongue cancer cell lines, respectively.

\section{CONFLICTS OF INTEREST}

The authors have no conflicts of interest.

\section{FUNDING}

The authors are gratefully acknowledged for financial support from J. C. Bose Fellowship from Department of Science \& Technology (SR/S2/JCB80/2007), Government of India (to BCD) and from Department of Biotechnology (6242-P34/RGCB/PMD/ DBT/ALCB/2015), Government of India (to ACB). This study was also supported by grants from the ICMR-Senior Research Fellowship to PK (3/2/2/272/2014/NCD-III) and SG (3/2/2/23/2010/NCD-III).

\section{Editorial note}

This paper has been accepted based in part on peerreview conducted by another journal and the authors' response and revisions as well as expedited peer-review in Oncotarget.

\section{REFERENCES}

1. Moore SR, Johnson NW, Pierce AM, Wilson DF. The epidemiology of tongue cancer: a review of global incidence. Oral Dis. 2000; 6:75-84.

2. Sano D, Myers JN. Metastasis of squamous cell carcinoma of the oral tongue. Cancer Metastasis Rev. 2007; 26:64562. https://doi.org/10.1007/s10555-007-9082-y.

3. Elango KJ, Suresh A, Erode EM, Subhadradevi L, Ravindran HK, Iyer SK, Kuriakose MA. Role of human papilloma virus in oral tongue squamous cell carcinoma. Asian Pac J Cancer Prev. 2011; 12:889-96.

4. Lee SY, Cho NH, Choi EC, Baek SJ, Kim WS, Shin DH, Kim SH. Relevance of human papilloma virus (HPV) infection to carcinogenesis of oral tongue cancer. Int J Oral Maxillofac Surg. 2010; 39:678-83. https://doi. org/10.1016/j.ijom.2010.03.014. 
5. Petersen PE. Oral cancer prevention and control-the approach of the World Health Organization. Oral Oncol. 2009; 45:454-60. https://doi.org/10.1016/j. oraloncology.2008.05.023.

6. Gupta S, Kumar P, Kaur H, Sharma N, Saluja D, Bharti AC, Das BC. Selective participation of c-Jun with Fra-2/c-Fos promotes aggressive tumor phenotypes and poor prognosis in tongue cancer. Scientific Reports. 2015; 5: 16811.

7. Mashberg A, Boffetta P, Winkelman R, Garfinkel L. Tobacco smoking, alcohol drinking, and cancer of the oral cavity and oropharynx among U.S. veterans. Cancer. 1993; 72:1369-75.

8. Boffetta P, Mashberg A, Winkelmann R, Garfinkel L. Carcinogenic effect of tobacco smoking and alcohol drinking on anatomic sites of the oral cavity and oropharynx. Int J Cancer. 1992; 52:530-3.

9. Gupta S, Kumar P, Das BC. HPV: Molecular pathways and targets. Curr Probl Cancer. 2018; 42:161-74. https://doi. org/10.1016/j.currproblcancer.2018.03.003.

10. Licitra L, Perrone F, Bossi P, Suardi S, Mariani L, Artusi R, Oggionni M, Rossini C, Cantu G, Squadrelli M, Quattrone P, Locati LD, Bergamini $\mathrm{C}$, et al. High-risk human papillomavirus affects prognosis in patients with surgically treated oropharyngeal squamous cell carcinoma. J Clin Oncol. 2006; 24:5630-6. https://doi.org/10.1200/JCO.2005.04.6136.

11. Lowy DR, Munger K. Prognostic implications of HPV in oropharyngeal cancer. N Engl J Med. 2010; 363:82-4. https://doi.org/10.1056/NEJMe1003607.

12. Mishra A, Bharti AC, Varghese P, Saluja D, Das BC. Differential expression and activation of NF-kappaB family proteins during oral carcinogenesis: Role of high risk human papillomavirus infection. Int J Cancer. 2006; 119:2840-50. https://doi.org/10.1002/ijc.22262.

13. Ringstrom E, Peters E, Hasegawa M, Posner M, Liu M, Kelsey KT. Human papillomavirus type 16 and squamous cell carcinoma of the head and neck. Clin Cancer Res. 2002; 8:3187-92.

14. Baldwin AS Jr. The NF-kappa B and I kappa B proteins: new discoveries and insights. Annu Rev Immunol. 1996; 14:649-83. https://doi.org/10.1146/annurev. immunol.14.1.649.

15. Prusty BK, Das BC. Constitutive activation of transcription factor AP-1 in cervical cancer and suppression of human papillomavirus (HPV) transcription and AP-1 activity in HeLa cells by curcumin. Int J Cancer. 2005; 113:951-60. https://doi.org/10.1002/ijc.20668.

16. Belguise K, Sonenshein GE. PKCtheta promotes c-Reldriven mammary tumorigenesis in mice and humans by repressing estrogen receptor alpha synthesis. J Clin Invest. 2007; 117:4009-21.

17. Nakayama H, Ikebe T, Beppu M, Shirasuna K. High expression levels of nuclear factor kappaB, IkappaB kinase alpha and Akt kinase in squamous cell carcinoma of the oral cavity. Cancer. 2001; 92:3037-44.

18. Chung CH, Parker JS, Ely K, Carter J, Yi Y, Murphy BA, Ang KK, El-Naggar AK, Zanation AM, Cmelak AJ, Levy $\mathrm{S}$, Slebos RJ, Yarbrough WG. Gene expression profiles identify epithelial-to-mesenchymal transition and activation of nuclear factor-kappaB signaling as characteristics of a high-risk head and neck squamous cell carcinoma. Cancer Res. 2006; 66:8210-8. https://doi.org/10.1158/0008-5472. CAN-06-1213.

19. Wang Y, Lin Z, Sun L, Fan S, Huang Z, Zhang D, Yang Z, Li J, Chen W. Akt/Ezrin Tyr353/NF-kappaB pathway regulates EGF-induced EMT and metastasis in tongue squamous cell carcinoma. Br J Cancer. 2013; 110:695-705. https://doi.org/10.1038/bjc.2013.770.

20. Sovak MA, Bellas RE, Kim DW, Zanieski GJ, Rogers AE, Traish AM, Sonenshein GE. Aberrant nuclear factorkappaB/Rel expression and the pathogenesis of breast cancer. J Clin Invest. 1997; 100:2952-60. https://doi. org/10.1172/JCI119848.

21. Cogswell PC, Guttridge DC, Funkhouser WK, Baldwin AS Jr. Selective activation of NF-kappa B subunits in human breast cancer: potential roles for NF-kappa B2/p52 and for Bcl-3. Oncogene. 2000; 19:1123-31. https://doi. org/10.1038/sj.onc. 1203412 .

22. Geismann C, Grohmann F, Sebens S, Wirths G, Dreher A, Hasler R, Rosenstiel P, Hauser C, Egberts JH, Trauzold A, Schneider G, Sipos B, Zeissig S, et al. c-Rel is a critical mediator of NF-kappaB-dependent TRAIL resistance of pancreatic cancer cells. Cell Death Dis. 2014; 5:e1455. https://doi.org/10.1038/cddis.2014.417.

23. Carrasco D, Rizzo CA, Dorfman K, Bravo R. The v-rel oncogene promotes malignant T-cell leukemia/lymphoma in transgenic mice. EMBO J. 1996; 15:3640-50.

24. Ramos JC, Ruiz P Jr, Ratner L, Reis IM, Brites C, Pedroso C, Byrne GE Jr, Toomey NL, Andela V, Harhaj EW, Lossos IS, Harrington WJ Jr. IRF-4 and c-Rel expression in antiviralresistant adult T-cell leukemia/lymphoma. Blood. 2007; 109:3060-8. https://doi.org/10.1182/blood-2006-07-036368.

25. Gillison ML. Human papillomavirus and prognosis of oropharyngeal squamous cell carcinoma: implications for clinical research in head and neck cancers. J Clin Oncol. 2006; 24:5623-5. https://doi.org/10.1200/JCO.2006.07.1829.

26. Jo S, Juhasz A, Zhang K, Ruel C, Loera S, Wilczynski SP, Yen Y, Liu X, Ellenhorn J, Lim D, Paz B, Somlo G, Vora $\mathrm{N}$, et al. Human papillomavirus infection as a prognostic factor in oropharyngeal squamous cell carcinomas treated in a prospective phase II clinical trial. Anticancer Res. 2009; 29:1467-74.

27. Shaw R, Robinson M. The increasing clinical relevance of human papillomavirus type 16 (HPV-16) infection in oropharyngeal cancer. Br J Oral Maxillofac Surg. 2010; 49:423-9. https://doi.org/10.1016/j.bjoms.2010.06.023. 
28. Syrjanen S. The role of human papillomavirus infection in head and neck cancers. Ann Oncol. 2010; 21:vii243-5. https://doi.org/10.1093/annonc/mdq454

29. Stransky N, Egloff AM, Tward AD, Kostic AD, Cibulskis K, Sivachenko A, Kryukov GV, Lawrence MS, Sougnez C, McKenna A, Shefler E, Ramos AH, Stojanov P, et al. The mutational landscape of head and neck squamous cell carcinoma. Science. 2011; 333:1157-60. https://doi. org/10.1126/science. 1208130.

30. The Cancer Genome Atlas Network. Comprehensive genomic characterization of head and neck squamous cell carcinomas. Nature. 2015; 517:576.

31. Upadhyay P, Gardi N, Desai S, Chandrani P, Joshi A, Dharavath B, Arora P, Bal M, Nair S, Dutt A. Genomic characterization of tobacco/nut chewing HPV-negative early stage tongue tumors identify MMP10 asa candidate to predict metastases. Oral Oncol. 2017; 73:56-64. https://doi. org/10.1016/j.oraloncology.2017.08.003.

32. Vettore AL, Ramnarayanan K, Poore G, Lim K, Ong CK, Huang KK, Leong HS, Chong FT, Lim TK, Lim WK, Cutcutache I, McPherson JR, Suzuki Y, et al. Mutational landscapes of tongue carcinoma reveal recurrent mutations in genes of therapeutic and prognostic relevance. Genome Med. 2015; 7:98.

33. Hayes C. HPV - Changing the Face of Head and Neck Cancer and Dental Societies' Responsibilities. Todays FDA. 2015; 27:38-9.

34. Bindhu OS, Ramadas K, Sebastian P, Pillai MR. High expression levels of nuclear factor kappa $\mathrm{B}$ and gelatinases in the tumorigenesis of oral squamous cell carcinoma. Head Neck. 2006; 28:916-25. https://doi.org/10.1002/hed.20437.

35. Hussain S, Bharti AC, Salam I, Bhat MA, Mir MM, Hedau S, Siddiqi MA, Basir SF, Das BC. Transcription factor AP-1 in esophageal squamous cell carcinoma: alterations in activity and expression during human Papillomavirus infection. BMC Cancer. 2009; 9: 329. https://doi. org/10.1186/1471-2407-9-329.

36. Vancurova I, Wu R, Miskolci V, Sun S. Increased p50/p50 NF-kappaB activation in human papillomavirus type 6- or type 11-induced laryngeal papilloma tissue. J Virol. 2002; $76: 1533-6$.

37. Gilmore TD. The Rel/NF-kappaB signal transduction pathway: introduction. Oncogene. 1999; 18:6842-4. https:// doi.org/10.1038/sj.onc. 1203237.

38. Ahmed KM, Dong S, Fan M, Li JJ. Nuclear factor-kappaB p65 inhibits mitogen-activated protein kinase signaling pathway in radioresistant breast cancer cells. Mol Cancer Res. 2006; 4:945-55. https://doi.org/10.1158/1541-7786. MCR-06-0291.

39. Hacke K, Rincon-Orozco B, Buchwalter G, Siehler SY, Wasylyk B, Wiesmuller L, Rosl F. Regulation of MCP-1 chemokine transcription by p53. Mol Cancer. 2010; 9:82. https://doi.org/10.1186/1476-4598-9-82.

40. Kleine-Lowinski K, Gillitzer R, Kuhne-Heid R, Rosl F. Monocyte-chemo-attractant-protein-1 (MCP-1)-gene expression in cervical intra-epithelial neoplasias and cervical carcinomas. Int J Cancer. 1999; 82:6-11. https:// doi.org/10.1002/(SICI)1097-0215(19990702)82:1<6::AIDIJC2>3.0.CO;2-3.

41. Field JK, Spandidos DA, Stell PM, Vaughan ED, Evan GI, Moore JP. Elevated expression of the c-myc oncoprotein correlates with poor prognosis in head and neck squamous cell carcinoma. Oncogene. 1989; 4:1463-8.

42. Sklar MD, Thompson E, Welsh MJ, Liebert M, Harney J, Grossman HB, Smith M, Prochownik EV. Depletion of c-myc with specific antisense sequences reverses the transformed phenotype in ras oncogene-transformed NIH 3T3 cells. Mol Cell Biol. 1991; 11:3699-710.

43. Smith LM, Wise SC, Hendricks DT, Sabichi AL, Bos T, Reddy P, Brown PH, Birrer MJ. cJun overexpression in MCF-7 breast cancer cells produces a tumorigenic, invasive and hormone resistant phenotype. Oncogene. 1999; 18:6063-70. https://doi.org/10.1038/sj.onc.1202989.

44. Wolfer A, Ramaswamy S. MYC and metastasis. Cancer Res. 2011; 71:2034-7. https://doi.org/10.1158/0008-5472. CAN-10-3776.

45. Hartl M, Bister K. Specific activation in jun-transformed avian fibroblasts of a gene (bkj) related to the avian betakeratin gene family. Proc Natl Acad Sci U S A. 1995; 92:11731-5.

46. Wisdom R, Johnson RS, Moore C. c-Jun regulates cell cycle progression and apoptosis by distinct mechanisms. EMBO J. 1999; 18:188-97. https://doi.org/10.1093/emboj/18.1.188.

47. Gartel AL, Ye X, Goufman E, Shianov P, Hay N, Najmabadi F, Tyner AL. Myc represses the p21 (WAF1/ CIP1) promoter and interacts with $\mathrm{Sp} 1 / \mathrm{Sp} 3$. Proc Natl Acad Sci U S A. 2001; 98:4510-5. https://doi.org/10.1073/ pnas.081074898.

48. Seoane J, Le HV, Massague J. Myc suppression of the p21 (Cip1) Cdk inhibitor influences the outcome of the p53 response to DNA damage. Nature. 2002; 419:729-34. https://doi.org/10.1038/nature01119.

49. Yang W, Shen J, Wu M, Arsura M, FitzGerald M, Suldan Z, Kim DW, Hofmann CS, Pianetti S, Romieu-Mourez R, Freedman LP, Sonenshein GE. Repression of transcription of the p27 (Kip1) cyclin-dependent kinase inhibitor gene by c-Myc. Oncogene. 2001; 20:1688-702. https://doi. org/10.1038/sj.onc.1204245.

50. Fredersdorf S, Burns J, Milne AM, Packham G, Fallis L, Gillett CE, Royds JA, Peston D, Hall PA, Hanby AM, Barnes DM, Shousha S, O'Hare MJ, et al. High level expression of p27 (kip1) and cyclin D1 in some human breast cancer cells: inverse correlation between the expression of p27 (kip1) and degree of malignancy in human breast and colorectal cancers. Proc Natl Acad Sci U S A. 1997; 94:6380-5.

51. Mineta H, Borg A, Dictor M, Wahlberg P, Akervall J, Wennerberg J. p53 mutation, but not p53 overexpression, correlates with survival in head and neck squamous cell carcinoma. Br J Cancer. 1998; 78:1084-90. 
52. Fontaine V, van der Meijden E, de Graaf J, ter Schegget J, Struyk L. A functional NF-kappaB binding site in the human papillomavirus type 16 long control region. Virology. 2000; 272:40-9.

53. Spitkovsky D, Hehner SP, Hofmann TG, Moller A, Schmitz ML. The human papillomavirus oncoprotein E7 attenuates NF-kappa B activation by targeting the Ikappa B kinase complex. J Biol Chem. 2002; 277:25576-82. https://doi. org/10.1074/jbc.M201884200.

54. White JS, Weissfeld JL, Ragin CC, Rossie KM, Martin CL, Shuster M, Ishwad CS, Law JC, Myers EN, Johnson JT, Gollin SM. The influence of clinical and demographic risk factors on the establishment of head and neck squamous cell carcinoma cell lines. Oral Oncol. 2007; 43:701-12. https:// doi.org/10.1016/j.oraloncology.2006.09.001.
55. Tatake RJ, Rajaram N, Damle RN, Balsara B, Bhisey AN, Gangal SG. Establishment and characterization of four new squamous cell carcinoma cell lines derived from oral tumors. J Cancer Res Clin Oncol. 1990; 116:179-86.

56. Franceschini A, Szklarczyk D, Frankild S, Kuhn M, Simonovic M, Roth A, Lin J, Minguez P, Bork P, von Mering C, Jensen LJ. STRING v9.1: protein-protein interaction networks, with increased coverage and integration. Nucleic Acids Res. 2013; 41: D808-15. https:// doi.org/10.1093/nar/gks1094. 